\title{
Intracellular Bicarbonate Regulates Action Potential Generation via KCNQ Channel Modulation
}

\author{
Ryan T. Jones, ${ }^{1}$ Guido C. Faas, ${ }^{2}$ and Istvan Mody ${ }^{2,3}$ \\ Departments of ${ }^{1}$ Neurobiology Graduate Program, ${ }^{2}$ Departments of Neurology, and ${ }^{3}$ Physiology, The David Geffen School of Medicine, University of \\ California Los Angeles, Los Angeles, California 90095
}

\begin{abstract}
Bicarbonate $\left(\mathrm{HCO}_{3}^{-}\right)$is an abundant anion that regulates extracellular and intracellular $\mathrm{pH}$. Here, we use patch-clamp techniques to assess regulation of hippocampal CA3 pyramidal cell excitability by $\mathrm{HCO}_{3}^{-}$in acute brain slices from $\mathrm{C} 57 \mathrm{BL} / 6 \mathrm{mice}$. We found that increasing $\mathrm{HCO}_{3}^{-}$levels enhances action potential (AP) generation in both the soma and axon initial segment (AIS) by reducing Kv7/ KCNQ channel activity, independent of $\mathrm{pH}$ (i.e., at a constant $\mathrm{pH}$ of 7.3). Conversely, decreasing intracellular $\mathrm{HCO}_{3}^{-}$leads to attenuation of AP firing. We show that $\mathrm{HCO}_{3}^{-}$interferes with $\mathrm{Kv} 7 / \mathrm{KCNQ}$ channel activation by phosphatidylinositol-4,5-biphosphate. Consequently, we propose that, even in the presence of a local depolarizing $\mathrm{Cl}^{-}$gradient, $\mathrm{HCO}_{3}^{-}$efflux through $\mathrm{GABA}_{\mathrm{A}}$ receptors may ensure the inhibitory effect of axoaxonic cells at the AIS due to activation of Kv7/KCNQ channels.
\end{abstract}

\section{Introduction}

Bicarbonate $\left(\mathrm{HCO}_{3}^{-}\right)$is a key product of cellular respiration, resulting from the hydration of $\mathrm{CO}_{2}$ and the subsequent deprotonation of carbonic acid. Thus, $\mathrm{HCO}_{3}^{-}$is one of the most abundant anions in cerebrospinal and intracellular fluids with a typical concentration of $\sim 26 \mathrm{~mm}$ at physiological $\mathrm{pH}(7.3-7.4)$ and $\mathrm{pCO}_{2}$ (5\%; Jungas, 2006; Casey et al., 2010). Bicarbonate acts as the major $\mathrm{pH}$ buffer in most biological systems (under physiological conditions for $\mathrm{CO}_{2} / \mathrm{HCO}_{3}^{-}, \mathrm{pK}_{\mathrm{a}}$ is $\sim 6.1$; Jungas, 2006; Casey et al., 2010). Hence, the steady-state intracellular and extracellular $\mathrm{HCO}_{3}^{-}$concentrations $\left(\left[\mathrm{HCO}_{3}^{-}\right]_{\mathrm{i}}\right.$ and $\left[\mathrm{HCO}_{3}^{-}\right]_{\mathrm{o}}$, respectively) and fluctuations thereof depend on local proton concentration (i.e., $\mathrm{pH}$ ). For example, in both vertebrate and crayfish neurons $\mathrm{HCO}_{3}^{-}$flux through $\mathrm{GABA}_{\mathrm{A}}$ receptor channels controls neuronal excitability by changing local $\mathrm{pH}$ (Chesler and Kaila, 1992; Jungas, 2006; Casey et al., 2010). Moreover, disturbance in this signaling mechanism might play an important role in some forms of epilepsy, and manipulation of brain $\mathrm{pH}$ may be a promising approach to therapeutic intervention (Pavlov et al., 2013). Apart from its well defined role as a $\mathrm{pH}$ buffer, $\mathrm{HCO}_{3}^{-}$also is a weak $\mathrm{Ca}^{2+}$ buffer, with a $\mathrm{K}_{\mathrm{d}} \sim 96 \mathrm{mM}$ (Greenwald, 1941; Nakayama, 1971; Jacobson and Langmuir, 1974; Reardon and Langmuir, 1974; Schaer, 1974; Fry and Poolewilson, 1981; Hablitz and Heinemann, 1987). Despite a relatively low affinity for free $\mathrm{Ca}^{2+}$, we initially hypothesized that the relatively high $\left[\mathrm{HCO}_{3}^{-}\right]_{\mathrm{i}}$ may provide physiologically relevant $\mathrm{Ca}^{2+}$ buffering, resulting in the

\footnotetext{
Received Sept. 8, 2013; revised Feb. 11, 2014; accepted Feb. 18, 2014.

Author contributions: R.T.J., G.C.F., and I.M. designed research; R.T.J. performed research; R.T.J., G.C.F., and I.M. analyzed data; R.T.J., G.C.F., and I.M. wrote the paper.

This work was supported by the US National Institutes of Health Grant 5T32NS058280 to R.T.J., R21AG037151 to G.C.F., and R01NS075429 and the Coelho Endowment to I.M.

The authors declare no competing financial interests.

Correspondence should be addressed to either Dr Istvan Mody or Dr Guido Faas, 635 Charles Young Drive South, NRB1 Rm 575D, Los Angeles, CA 90095, E-mail: mody@ucla.edu or gfaas@ucla.edu.

DOI:10.1523/JNEUROSCI.3836-13.2014

Copyright $\odot 2014$ the authors $\quad 0270-6474 / 14 / 344409-09 \$ 15.00 / 0$
}

modulation of neuronal excitability. To test this hypothesis, we examined the effects of changing $\left[\mathrm{HCO}_{3}^{-}\right]_{\mathrm{i}}$, at a set $\mathrm{pH}$ of 7.3 , on the firing properties of hippocampal CA3 pyramidal cells (PCs), a cell type that lacks major $\mathrm{Ca}^{2+}$ buffering proteins such as parvalbumin, calbindin, and calretinin (Schwaller, 2010). We found that $\mathrm{HCO}_{3}^{-}$has a significant effect on neuronal excitability, independent of $\mathrm{pH}$. However, contrary to our initial hypothesis, the effects of $\mathrm{HCO}_{3}^{-}$are not due to a direct modulation of $\mathrm{Ca}^{2+}$ signaling, but rather to an inhibition of Kv7/KCNQ channel activity. Moreover, fluctuations in $\left[\mathrm{HCO}_{3}^{-}\right]_{\mathrm{i}}$ may control $\mathrm{Kv} 7 /$ KCNQ channel activation through a phosphatidylinositol-4,5biphosphate $\left(\mathrm{PIP}_{2}\right)$-dependent mechanism.

\section{Materials and Methods}

Electrophysiology. Horizontal hippocampal brain slices $(350 \mu \mathrm{m})$ were prepared from male C57BL/6J (4-6 weeks) mice according to protocols approved by the UCLA Chancellor's Animal Research Committee. Mice were deeply anesthetized with isofluorane, avoiding all handling and stress to the animals, and were decapitated using a guillotine. Their brains were quickly removed and cooled to $4^{\circ} \mathrm{C}$ in a sodium-free cutting solution containing the following (in mM): $135 \mathrm{~N}$-methyl-D-glucamine, 26 HEPES, 10 D-glucose, $4 \mathrm{MgCl}_{2}, 1.2 \mathrm{KH}_{2} \mathrm{PO}_{4}, 1 \mathrm{KCl}$, and $0.5 \mathrm{CaCl}_{2}$ (bubbled with $100 \% \mathrm{O}_{2}, \mathrm{pH} 7.4,290-300 \mathrm{mOsm}$ ). Slices were cut in the same sodium-free solution using a Leica V1200S vibratome and subsequently transferred to an interface holding chamber containing a reduced sodium artificial CSF (aCSF) at $32^{\circ} \mathrm{C}$ containing the following (in $\mathrm{mm}$ ): $85 \mathrm{NaCl}$, 55 sucrose, 25 D-glucose, 26 HEPES, $4 \mathrm{MgCl}_{2}, 2.5 \mathrm{KCl}$, $1.25 \mathrm{NaH}_{2} \mathrm{PO}_{4}, 0.5 \mathrm{CaCl}_{2}$ (bubbled with $100 \% \mathrm{O}_{2}, \mathrm{pH} 7.4,290-300$ $\mathrm{mOsm})$. After $30 \mathrm{~min}$, the slices were allowed to cool to room temperature $\left(22-23^{\circ} \mathrm{C}\right)$ and kept in this solution until used for recordings. Brain slices were transferred to a submerged recording chamber at $34^{\circ} \mathrm{C}$ and perfused at $5 \mathrm{ml} / \mathrm{min}$ with aCSF containing the following (in $\mathrm{mM}$ ): 126 $\mathrm{NaCl}, 26$ HEPES, 10 D-glucose, $2.5 \mathrm{KCl}, 2 \mathrm{MgCl}_{2}, 2 \mathrm{CaCl}_{2}, 1.25$ $\mathrm{NaH}_{2} \mathrm{PO}_{4}, 1.5 \mathrm{Na}$-pyruvate, and $1 \mathrm{~L}$-glutamine $\left(100 \% \mathrm{O}_{2}, \mathrm{pH} 7.4,290-\right.$ $300 \mathrm{mOsm}$ ). All salts were purchased from Sigma-Aldrich. DNQX (25 $\mu \mathrm{M})$, D-AP5 $(50 \mu \mathrm{M})$ and gabazine or picrotoxin $(20$ or $100 \mu \mathrm{M}$, respectively) were added to block ionotropic glutamatergic and GABAergic transmission (Tocris Biosciences). Slices were visualized under IR-DIC 

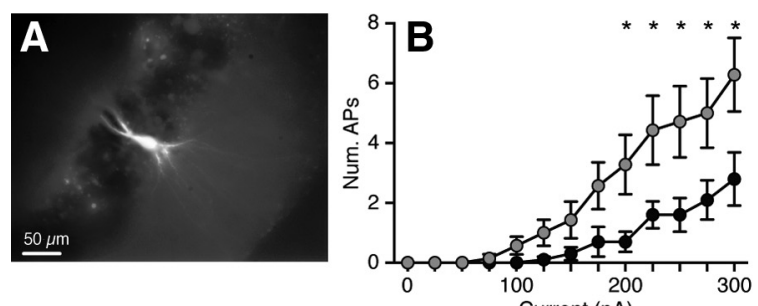

C

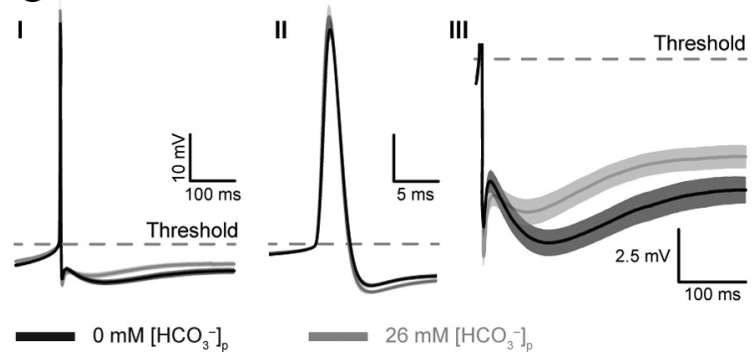

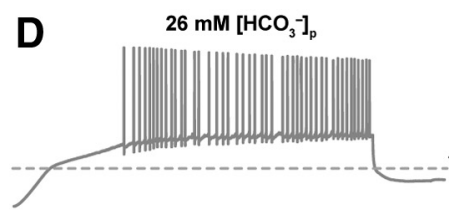
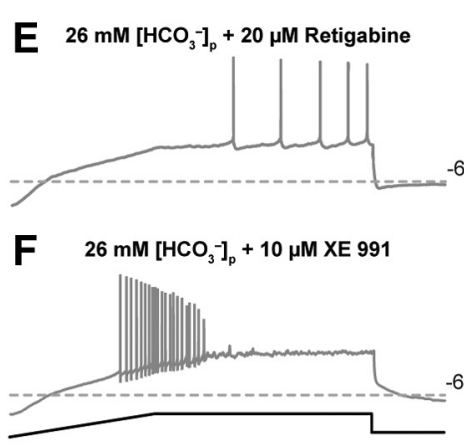

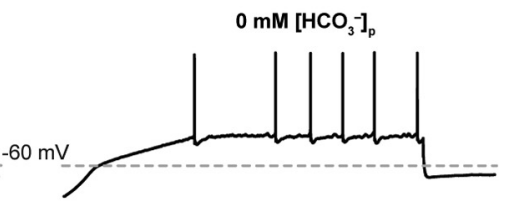

$0 \mathrm{mM}\left[\mathrm{HCO}_{3}^{-}\right]_{\mathrm{p}}+20 \mu \mathrm{M}$ Retigabine
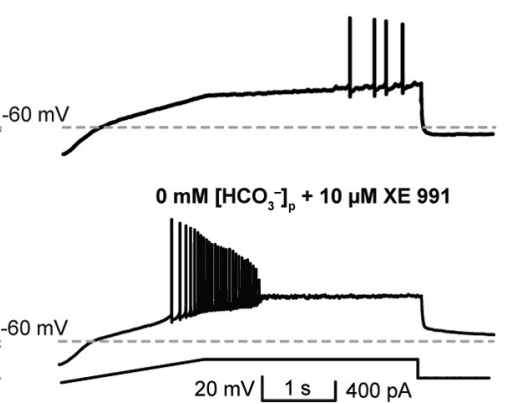

Figure 1. Intracellular $\mathrm{HCO}_{3}^{-}$regulates intrinsic excitability via $\mathrm{KCNQ}$ channel activation. $A$, Whole-cell current-clamp recordings were made from CA3 $\mathrm{PCS}$. A subset of recorded neurons was filled with AlexaFluor $488(50 \mu \mathrm{m})$ to confirm CA3 PC morphology. $\boldsymbol{B}$, Current steps $(300 \mathrm{~ms})$ evoked fewer APs with $0 \mathrm{~mm}\left[\mathrm{HCO}_{3}^{-}\right]_{p^{\prime}}$, black traces versus $26 \mathrm{~mm}\left[\mathrm{HCO}_{3}^{-}\right]_{\mathrm{p}^{\prime}}$ gray traces ( $n=10, p=0.01$, RM two-way ANOVA; asterisks indicate statistically significant post hoc paired tests). C, Spontaneous AP waveforms recorded with 0 or $26 \mathrm{~mm}\left[\mathrm{HCO}_{3}^{-}\right]_{\mathrm{p}}$ revealed significantly enhanced $\mathrm{mAHP}(\boldsymbol{C I}, \mathrm{CIII})$ in $0 \mathrm{~mm}\left[\mathrm{HCO}_{3}^{-}\right]_{\mathrm{p}}$, whereas AP amplitude, threshold, and half-width were unaltered $(\boldsymbol{C I I})$. $\boldsymbol{D}$, Current ramp protocols $(\boldsymbol{F}$, bottom) also revealed reduced AP generation in 0 versus $26 \mathrm{~mm}\left[\mathrm{HCO}_{3}^{-}\right]_{\mathrm{p}^{\prime}}$, indicating reduced excitability. $\boldsymbol{E}$, The KCNQ channel activator retigabine $(20 \mu \mathrm{M})$ reduced the number of APs/ramp in $26 \mathrm{~mm}\left[\mathrm{HCO}{ }_{3}^{-}\right]_{\mathrm{p}}$ to levels comparable to $0 \mathrm{~mm}\left[\mathrm{HCO}_{3}^{-}\right]_{\mathrm{p}}$. $F$, In contrast, the KCNQ channel antagonist XE $991(10 \mu \mathrm{M})$ increased the number of APs in both 0 and $26 \mathrm{~mm}\left[\mathrm{HCO}_{3}^{-}\right]_{\mathrm{p}}$ and removed the difference between conditions. Data shown as mean \pm SEM.

upright microscope (Olympus BX-51WI, 20× XLUMPlan FL N objective) and whole-cell recordings were obtained from CA3 pyramidal neurons with borosilicate patch pipettes (4-6 M $\Omega$, King Precision Glass) containing a mixture (according to the desired $\left[\mathrm{HCO}_{3}^{-}\right]_{\mathrm{p}}$, see below) of two internal solutions: (1) $0 \mathrm{~mm} \mathrm{HCO}_{3}^{-}$solution (in $\mathrm{mm}$ ): 135 K-methanesulphonate, $5 \mathrm{KCl}, 10 \mathrm{HEPES}, 2 \mathrm{MgCl}_{2}, 3 \mathrm{NaCl}, 0.2$ EGTA, 2 $\mathrm{Na}_{2}$ ATP, 0.2 NaGTP, pH 7.3-7.35 with $\mathrm{KOH}$; or (2) $26 \mathrm{~mm} \mathrm{HCO}_{3}^{-}$ solution (in $\mathrm{mM}$ ): $120 \mathrm{~K}$-methanesulphonate, $15 \mathrm{KHCO}_{3}, 5 \mathrm{KCl}, 10$ HEPES, $2 \mathrm{MgCl}_{2}, 3 \mathrm{NaCl}$, 0.2 EGTA, $2 \mathrm{Na}_{2} \mathrm{ATP}, 0.2 \mathrm{Na}_{2} \mathrm{GTP}$. The $\mathrm{pH}$ was set to $7.3-7.35$ while bubbling with $5 \% \mathrm{CO}_{2} / 95 \% \mathrm{O}_{2}$. Internal solutions were stored at $-80^{\circ} \mathrm{C}$ in one $\mathrm{ml}$ aliquots. Before each experiment, intracellular solution aliquots were thawed to room temperature and the 26 mM $\mathrm{HCO}_{3}^{-}$containing intracellular solution (solution 2) was bubbled with $5 \% \mathrm{CO}_{2} / 95 \% \mathrm{O}_{2}$ for $15-20 \mathrm{~min}$. The $\mathrm{pH}$ of both solutions was confirmed to be between 7.3 and 7.35 before each day's experiments. The liquid junction potential (LJP) was $+5 \mathrm{mV}$, but reported $V_{m}$ values have not been adjusted to account for the LJP. The $\mathrm{pH}$ drift of the $\mathrm{HCO}_{3}^{-}$ containing intracellular solution was confirmed to be $<0.1 \mathrm{pH} / \mathrm{h}$ when sealed in an airtight tube. If the $\mathrm{HCO}_{3}^{-}$intracellular solution was exposed to the air, the $\mathrm{pH}$ gradually became more alkaline, drifting to $\mathrm{pH} \sim 7.6$ as $\mathrm{CO}_{2}$ left solution, but had a very slow time constant of $\sim 4.5 \mathrm{~h}$. The $26 \mathrm{~mm}$ $\mathrm{HCO}_{3}^{-}$intracellular solution was diluted $1: 2$ or $1: 4$ with the $0 \mathrm{mM} \mathrm{HCO}_{3}^{-}$ solution to produce 13 or $6.5 \mathrm{~mm}$ containing pipette solutions, respectively. In a subset of recordings, AlexaFluor 488 dextran $(50 \mu \mathrm{M}$, Tocris Bioscience) was included in the pipette solution to verify the neuronal morphology of CA3 neurons (Fig. 1A). For PIP ${ }_{2}$ experiments, $\mathrm{PIP}_{2}$ (Echelon Biosciences) was dissolved in deionized water at a stock solution concentration of $1 \mu \mathrm{g} / \mu \mathrm{l}$ and stored at $-20^{\circ} \mathrm{C}$. Before each experiment, one aliquot of $\mathrm{PIP}_{2}$ was thawed and diluted into 0 $\mathrm{mm}\left[\mathrm{HCO}_{3}^{-}\right] \mathrm{K}$-Met pipet solution to a final concentration of 10 or $30 \mu \mathrm{M}$.

Recording and analysis. Recordings were obtained using a MultiClamp $700 \mathrm{~A}$ amplifier (Molecular Devices), low-pass filtered at $5 \mathrm{kHz}$ (Bessel, 8-pole) and digitized at $20 \mathrm{kHz}$ with a National Instruments data acquisition board (NI USB-6221). All recording protocols and analyses were performed using custom procedures written in Igor Pro (WaveMetrics).

Current-clamp protocol. After achieving stable whole-cell configuration in voltage-clamp, the amplifier was switched to current-clamp mode. Only recordings with series resistances $<20 \mathrm{M} \Omega$ were used and bridge balance compensation was applied while in current-clamp. After measuring the resting membrane potential, constant current was injected (no more than $\pm 50 \mathrm{pA}$ ) into the cell to keep its membrane potential between -60 and $-65 \mathrm{mV}$. Current steps $(300 \mathrm{~ms})$ from -100 to $+500 \mathrm{pA}$ were injected every $30 \mathrm{~s}$. To induce steady-state action potential (AP) firing, a steady current was injected through the pipette and was gradually increased until spontaneous action potentials were observed $(\sim-40$ to $-30 \mathrm{mV})$. Spontaneous APs were detected and extracted by calculating the second derivative of the membrane voltage deflection and defining AP initiation as the point at which the second derivative deviated significantly from zero. The second derivative was also used to determine AP threshold and was used as the reference point to measure AP amplitude, fast afterhyperpolarization (fAHP; immediately following the AP) amplitude and medium afterhyperpolarization area. The mAHP was defined as the hyperpolarization immediately following the fAHP and lasting $\sim 100 \mathrm{~ms}$ (Storm, 1987b, 1989). Statistical analysis of spontaneous AP threshold, amplitude, half-width, fAHP, and mAHP was performed by analyzing 10 consecutive APs and comparing 0 and 26 $\mathrm{mm}\left(\left[\mathrm{HCO}_{3}^{-}\right]_{\mathrm{p}}\right.$ conditions with a two-way repeated-measures (RM) ANOVA. Ramp protocols consisted of a $-100 \mathrm{pA}$ step for $1 \mathrm{~s}$, followed by a current ramp to $+400 \mathrm{pA}(250 \mathrm{pA} / \mathrm{s})$, and then a plateau stage for an additional $3 \mathrm{~s}$. Ramps were applied every $60 \mathrm{~s}$.

Antidromic action current protocols. Whole-cell voltage-clamp recordings were obtained with $0 \mathrm{~mm} \mathrm{HCO}_{3}^{-}$pipette solution containing AlexaFluor $488(50 \mu \mathrm{M})$ to visualize the axon. A theta glass electrode was positioned near the labeled axon $(\sim 250 \mu \mathrm{m}$ away from soma $)$ and antidromic action currents were evoked with 50-100 $\mu$ s stimuli. Stimulus trains were applied ( 5 stimuli, $50 \mathrm{~Hz}$ ) and the stimulus intensity was adjusted so that the probability of evoking an antidromic action current was $\sim 50 \%$.

Statistical analysis. Statistics were calculated using GraphPad Prism 6 and statistics procedures in $R$. Data are presented as mean \pm SEM. Nonparametric statistical analysis was used for datasets that deviated from normality (as determined using a QQ-plot) and the respective statistical tests are indicated in the text and figure legends. The median value $( \pm \mathrm{SE}$ of median) was reported in some cases, because it is a better representation of central tendency for skewed distributions compared with the mean. SE of medians was calculated using resampling procedures in $R$. For ANOVAs with significance levels $<0.05$, post hoc paired tests were performed and corrected for multiple comparisons. Significance level $(\alpha)$ was set to 0.05 . 
Table 1. Basic membrane properties of CA3 pyramidal neurons

\begin{tabular}{llllcr}
\hline$\left[\mathrm{HCO}_{3}^{-}\right]_{0}(\mathrm{mM})$ & 0 & 0 & 0 & 0 & \\
{$\left[\mathrm{HCO}_{3}^{-}\right]_{p}(\mathrm{~mm})$} & 0 & 6.5 & 13 & 26 & 0 \\
\hline Resting membrane potential $(\mathrm{mV})$ & $-63 \pm 1$ & $-57 \pm 2$ & $-60 \pm 1$ & $-63 \pm 2$ & $-66 \pm 1$ \\
Input resistance $(\mathrm{M} \Omega)$ & $181 \pm 12$ & $185 \pm 11$ & $222 \pm 30$ & $199 \pm 19$ & $202 \pm 26$ \\
$n$ & 23 & 5 & 8 & 14 & 0.208 \\
\hline
\end{tabular}

Resting membrane potentials and input resistances were not different across all $\mathrm{HCO}_{3}^{-}$conditions. Values are mean $\pm \mathrm{SEM}$. Statistical comparisons were calculated using one-way ANOVA.

Table 2. Spontaneous AP properties

\begin{tabular}{|c|c|c|c|}
\hline $\begin{array}{l}\left.\mathrm{HCO}_{3}^{-}\right]_{0}(\mathrm{~mm}) \\
{\left[\mathrm{HCO}_{3}^{-}\right]_{\mathrm{p}}(\mathrm{mm})}\end{array}$ & $\begin{array}{l}0 \\
0\end{array}$ & $\begin{array}{r}0 \\
26 \\
\end{array}$ & $p$ value \\
\hline Threshold $(\mathrm{mV})^{a}$ & $-29 \pm 0.2$ & $-31 \pm 0.1$ & 0.40 \\
\hline AP amplitude $(\mathrm{mV})^{a}$ & $49 \pm 0.6$ & $53 \pm 0.4$ & 0.12 \\
\hline Half-width $(\mu s)$ & $784 \pm 55$ & $768 \pm 39$ & 0.65 \\
\hline fAHP amplitude (mV) ${ }^{a}$ & $8.8 \pm 0.1$ & $10.5 \pm 0.1$ & $0.02^{*}$ \\
\hline $\mathrm{mAHP}$ area $(\mathrm{mV} \cdot \mathrm{s})^{a}$ & $-1.12 \pm 0.01$ & $-0.68 \pm 0.01$ & $<0.0001^{*}$ \\
\hline$n$ & 11 & 11 & \\
\hline
\end{tabular}

Fast AP properties were not significantly affected by $\left[\mathrm{HCO}_{3}^{-}\right]_{p}$. However, the area of the mAHP was significantly enhanced in $0 \mathrm{mM}\left[\mathrm{HCO}_{3}^{-}\right]_{\text {p }}$. Values are mean $\pm \mathrm{SEM}$.

${ }^{a}$ Measured relative to AP threshold. *Indicates statistical significance, two-way RM ANOVA.

\section{Results}

\section{Intracellular bicarbonate modulates CA3 pyramidal} cell excitability

To assess the influence of $\left[\mathrm{HCO}_{3}^{-}\right]_{\mathrm{i}}$ on neuronal excitability, AP firing properties were measured in $\mathrm{CA} 3 \mathrm{PCs}$ in acute hippocampal slices in $\mathrm{HCO}_{3}^{-}$-free $\left(0 \mathrm{~mm}\left[\mathrm{HCO}_{3}^{-}\right]_{\mathrm{o}} / \mathrm{HEPES}\right.$ buffered, $\mathrm{pH}$ 7.4) aCSF containing $25 \mu \mathrm{M}$ DNQX, $50 \mu \mathrm{M}$ D-APV, and either 20 $\mu \mathrm{M}$ gabazine or $100 \mu \mathrm{M}$ PTX to block AMPA, NMDA, and $\mathrm{GABA}_{\mathrm{A}}$ receptors, respectively. Whole-cell recordings were made using pipette solutions containing $0,6.5,13$, or $26 \mathrm{~mm}^{-} \mathrm{HCO}_{3}^{-}$ $\left(\left[\mathrm{HCO}_{3}^{-}\right]_{\mathrm{p}}\right)$ to set $\left[\mathrm{HCO}_{3}^{-}\right]_{\mathrm{i}}$. Because the conversion of $\mathrm{HCO}_{3}^{-}$to $\mathrm{CO}_{2}$ is catalyzed by multiple carbonic anhydrases and $\mathrm{CO}_{2}$ readily passes through the membrane (Maren, 1967), it is difficult to set $\left[\mathrm{HCO}_{3}^{-}\right]_{\mathrm{i}}$ to an exact value. However, varying $\left[\mathrm{HCO}_{3}^{-}\right]_{\mathrm{p}}$ will result in correspondingly different values of $\left[\mathrm{HCO}_{3}^{-}\right]_{\mathrm{i}}$. Importantly, to test the effect of $\left[\mathrm{HCO}_{3}^{-}\right]_{\mathrm{i}}$ independent of $\mathrm{pH}$, the $\mathrm{pH}$ was carefully set to 7.3 for each pipette solution directly before each experiment. Separate experiments confirmed that $\mathrm{pH}$ drift, due to $\mathrm{CO}_{2}$ dissipation out of the pipette solution, was minimal $(<0.1 \mathrm{pH}$ unit $)$ for the typical duration of an experiment.

To measure AP firing, square pulse current steps $(300 \mathrm{~ms}$, -100 to $+300 \mathrm{pA}$ ) were injected into PCs recorded with either 0 or $26 \mathrm{~mm}\left[\mathrm{HCO}_{3}^{-}\right]_{\mathrm{p}}$. PCs patched with $26 \mathrm{~mm}\left[\mathrm{HCO}_{3}^{-}\right]_{\mathrm{p}}$ exhibited greater intrinsic excitability, measured by the number of APs, than cells recorded with $0 \mathrm{~mm}\left[\mathrm{HCO}_{3}^{-}\right]_{\mathrm{p}}(n=10$ each, $p=0.013$, R.M. two-way ANOVA; Fig. 1 $A, B$ ), whereas resting membrane potentials and input resistances were unaffected (Table 1). Steady firing of spontaneous APs was elicited by gradually depolarizing the cells to -40 to $-35 \mathrm{mV}$ with constant current injections. AP properties were assessed at these depolarized potentials. We found that the area of the medium post-spike afterhyperpolarization (mAHP) was significantly larger with $0 \mathrm{mM}\left[\mathrm{HCO}_{3}^{-}\right]_{\mathrm{p}} \mathrm{com}-$ pared with $26 \mathrm{~mm}\left[\mathrm{HCO}_{3}^{-}\right]_{\mathrm{p}}\left(1.12 \pm 0.1\right.$ vs $0.68 \pm 0.1 \mathrm{mV}^{\star} \mathrm{s} ; n=$ 11 for both $\left[\mathrm{HCO}_{3}^{-}\right]_{\mathrm{p}}, p<0.0001$; Fig. $\left.1 \mathrm{CI}, \mathrm{CIII}\right)$. However, AP threshold, amplitude, and half-width, were unaffected (Fig. 1CII; Table 2). Bicarbonate can act as a weak $\mathrm{Ca}^{2+}$ buffer (Greenwald, 1941; Nakayama, 1971; Jacobson and Langmuir, 1974; Reardon and Langmuir, 1974; Schaer, 1974; Fry and Poolewilson, 1981; Hablitz and Heinemann, 1987) and if the effect of $\mathrm{HCO}_{3}^{-}$on the mAHP was $\mathrm{Ca}^{2+}$-dependent, adding a strong $\mathrm{Ca}^{2+}$-buffer or reducing $\mathrm{Ca}^{2+}$ entry should abolish this effect. However, the $\mathrm{mAHP}$ persisted in the presence of $5 \mathrm{~mm}$ intracellular BAPTA or
A
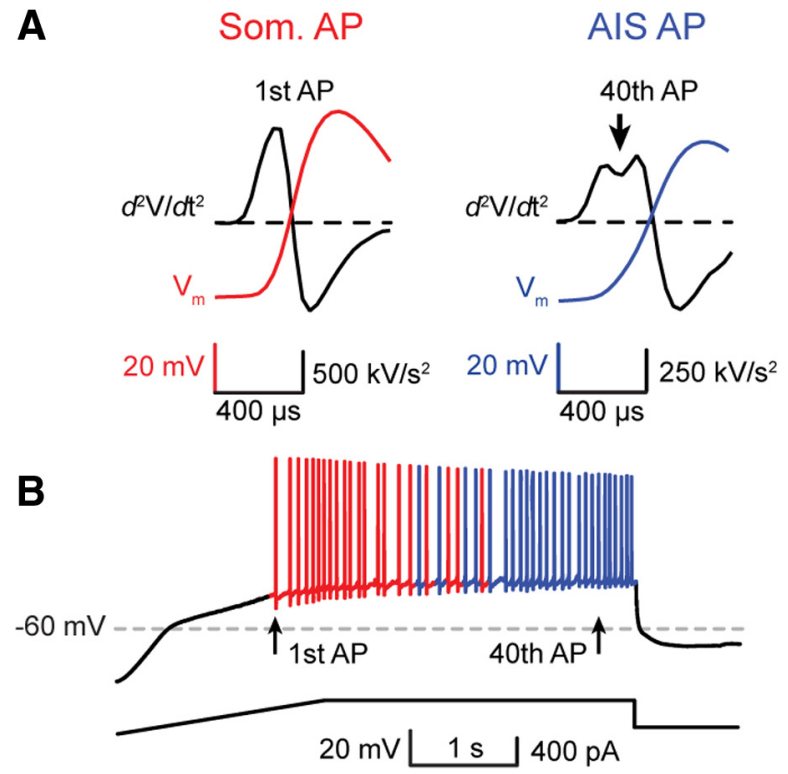

C

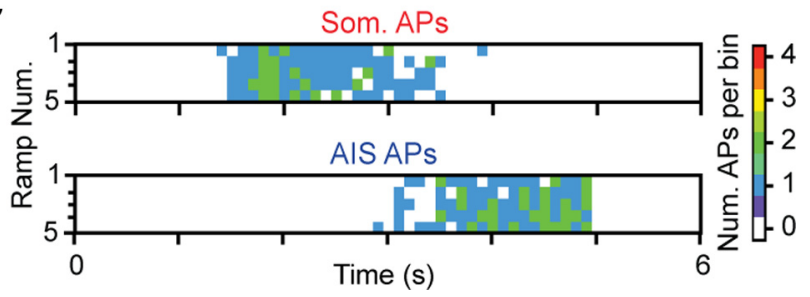

Figure 2. Detection and classification of somatic or axon initial segment generated APs. A, Somatic (Som.; red) or AIS (blue) generated APs were determined by calculating the second derivative of each AP. As shown by previous studies (Meeks and Mennerick, 2007), the second derivative of the voltage traces of somatically generated APs exhibit a biphasic waveform during the rising phase, whereas AIS-generated APs exhibit a pronounced biphasic dip (arrow). $\boldsymbol{B}$, The site of AP generation transitioned from the soma to AIS during current ramps, most likely due to the large somatic voltage change caused by the current ramp injection protocol, and was consistent and reproducible over multiple ramps (C). The color scale indicates the number of APs in $100 \mathrm{~ms}$ bins.

when $50 \mu \mathrm{M} \mathrm{Cd}^{2+}$ was added to the aCSF (data not shown), confirming earlier observations (Storm, 1987a), and indicating that the reduction of $\mathrm{mAHP}$ by $\mathrm{HCO}_{3}^{-}$was not due to fast modulation of $\mathrm{Ca}^{2+}$ signaling. In summary, these data indicate that intracellular $\mathrm{HCO}_{3}^{-}$regulates intrinsic CA3 PC excitability by modulating postspike mAHP, independent of $\mathrm{pH}$ and $\mathrm{Ca}^{2+}$.

\section{Intracellular bicarbonate regulates action potential} generation by modulating KCNQ channel activation Previous reports suggest that a major component of the mAHP in CA1 PCs is mediated by $\mathrm{Kv} 7 / \mathrm{KCNQ} \mathrm{K}^{+}$channels, regulating intrinsic neuronal excitability ( $\mathrm{Gu}$ et al., 2008; Tzingounis and Nicoll, 2008; Cooper, 2011; Klinger et al., 2011). Because the major effect of lowering $\left[\mathrm{HCO}_{3}^{-}\right]_{\mathrm{i}}\left(0 \mathrm{~mm}\left[\mathrm{HCO}_{3}^{-}\right]_{\mathrm{p}}\right)$ was a reduction in intrinsic excitability and an enhancement of the mAHP, we hypothesized that $\left[\mathrm{HCO}_{3}^{-}\right]_{\mathrm{i}}$ may regulate $\mathrm{KCNQ}$ channel ac- 

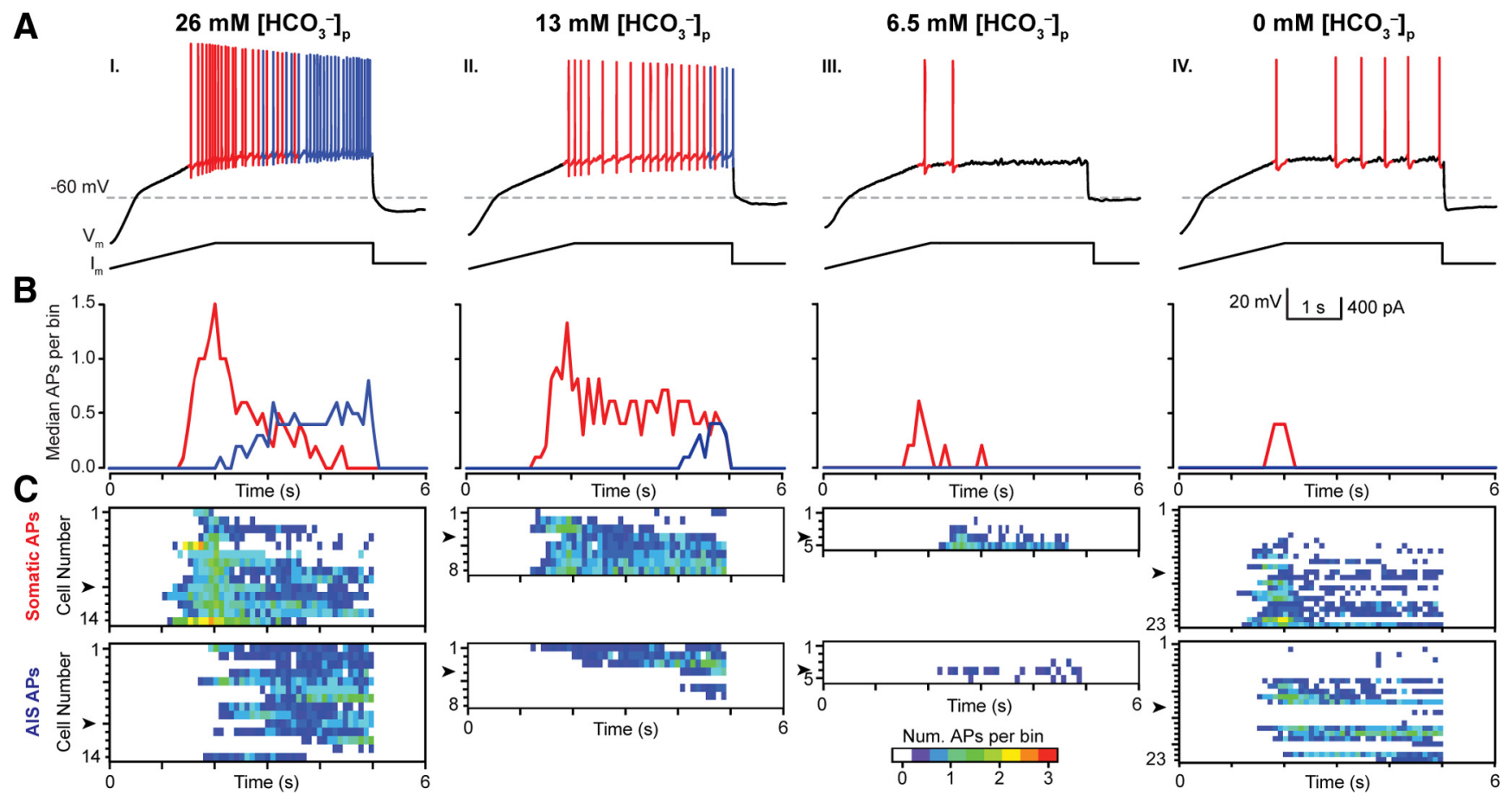

Figure 3. Intracellular $\mathrm{HCO}_{3}^{-}$modulates somatic and axon initial segment action potential generation. $\mathrm{A}, \mathrm{CA} 3 \mathrm{PCs}$ exhibit a $\left[\mathrm{HCO}_{3}^{-}\right]_{\mathrm{p}}$ dose-dependent reduction in the number of somatic (som, red) and AIS (blue) APs/ramp. B, Median spike time histograms ( $100 \mathrm{~ms} / \mathrm{bin}$ ) for all cells indicated in Cillustrate the evolution of som to AIS generated APs during the ramp. AI-AIV, Decreasing $\left[\mathrm{HCO}_{3}^{-}\right]_{\mathrm{p}}$ dramatically reduced the median number of som and AIS APs/bin. C, Evolution of AP firing during the ramps is displayed as heat maps in each recorded neuron for different $\left[\mathrm{HCO}_{3}^{-}\right]_{\mathrm{p}}$. Arrowheads indicate the representative neurons shown in $\boldsymbol{A}$.

tivation. Similar to previous reports in CA1 PCs (Gu et al., 2005), bath-application of the KCNQ selective antagonist XE 991 (10 $\mu \mathrm{M}$ ) abolished the mAHP in both 0 and $26 \mathrm{~mm}\left[\mathrm{HCO}_{3}^{-}\right]_{\mathrm{p}}$ (data not shown), confirming that KCNQ currents constitute a major component of the mAHP in CA3 PCs.

To establish whether $\left[\mathrm{HCO}_{3}^{-}\right]_{\mathrm{i}}$ can regulate PC excitability by modulating KCNQ channels, we used a current ramp protocol to elicit APs that are sensitive to KCNQ channel activation (Hu et al., 2007). When these ramp protocols were performed in $0 \mathrm{mM}$ $\left[\mathrm{HCO}_{3}^{-}\right]_{\mathrm{o}}$ with either 0 or $26 \mathrm{~mm}\left[\mathrm{HCO}_{3}^{-}\right]_{\mathrm{p}}$, we found that PCs recorded with $0 \mathrm{~mm}\left[\mathrm{HCO}_{3}^{-}\right]_{\mathrm{p}}$ generated significantly fewer APs/ ramp (median $=12 \pm 4 \mathrm{APs} / \mathrm{ramp}, n=23)$ compared with PCs recorded with $26 \mathrm{~mm}\left[\mathrm{HCO}_{3}^{-}\right]_{\mathrm{p}}$ (median $=36 \pm 4 \mathrm{APs} / \mathrm{ramp}$, $n=14, p=0.001$, Mann-Whitney; Fig. 1D). Bath application of the KCNQ channel activator retigabine $(20 \mu \mathrm{M})$ reduced the number of elicited APs/ramp with $26 \mathrm{~mm}\left[\mathrm{HCO}_{3}^{-}\right]_{\mathrm{p}}$ (median $=$ $4 \pm 3 \mathrm{APs} / \mathrm{ramp}, n=4)$ to levels comparable to $0 \mathrm{mM}\left[\mathrm{HCO}_{3}^{-}\right]_{\mathrm{p}}$ plus retigabine (median $=1 \pm 1 \mathrm{AP} / \mathrm{ramp}, n=4, p=0.36$, Mann-Whitney; Fig. 1E). In contrast, XE $991(10 \mu \mathrm{M})$ dramatically enhanced excitability in both 0 and $26 \mathrm{~mm}\left[\mathrm{HCO}_{3}^{-}\right]_{\mathrm{p}}$, resulting in depolarization block, and rendered AP firing comparable between conditions ( $0 \mathrm{~mm}$ : $19 \pm 4 \mathrm{APs} / \mathrm{ramp}, 26 \mathrm{~mm}$ : $22 \pm 11$ APs/ramp, median \pm SEM, $n=4$ each, $p=0.65$, MannWhitney; Fig. $1 F)$. Given these data, it is possible that $\left[\mathrm{HCO}_{3}^{-}\right]_{\mathrm{i}}$ regulates PC excitability by modulating KCNQ channel activation such that a decrease in $\left[\mathrm{HCO}_{3}^{-}\right]_{\mathrm{i}}$ increases KCNQ channel activity.

$\mathrm{Kv} 7 / \mathrm{KCNQ}$ channels are enriched at the axon initial segment (AIS) of pyramidal cells, where they associate with $\mathrm{Na}_{\mathrm{V}}$ channels via the scaffolding protein ankyrin-G and regulate AP initiation (Gu et al., 2005, 2008; Hu et al., 2007; Cooper, 2011). Because the AIS is the predominant site of AP generation in cortical PCs and has lower AP threshold than the soma (Meeks et al., 2005; Meeks

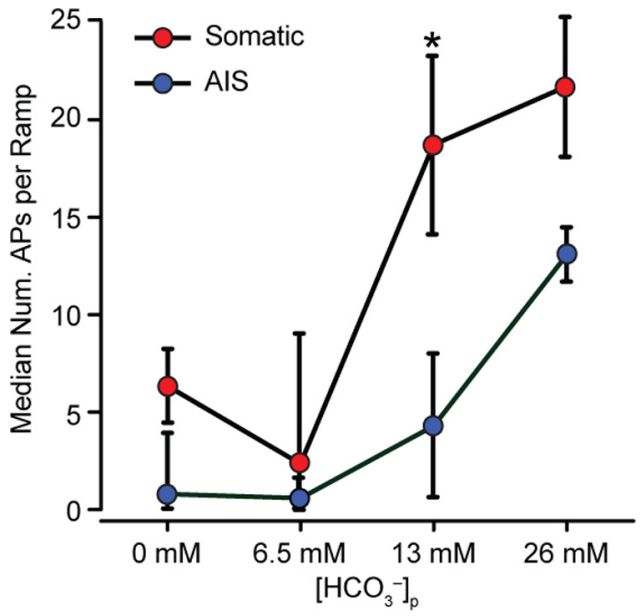

Figure 4. Intracellular $\mathrm{HCO}_{3}^{-}$regulates somatic and AIS AP generation. $A$, Two-way ANOVA shows a significant effect of $\left[\mathrm{HCO}_{3}^{-}\right]_{\mathrm{p}}$ on both somatic and AIS AP generation in $0 \mathrm{~mm}\left[\mathrm{HCO}_{3}^{-}\right]_{0}$ $\left(F_{(3,92)}=8.40, p<0.0001\right)$, and an interaction between som. and AIS generated APs $\left(F_{(3,92)}=\right.$ $2.76, p=0.046)$. AlS generated APs were particularly sensitive to a reduction of $\left[\mathrm{HCO}_{3}^{-}\right]_{\mathrm{p}}$ from 26 to $13 \mathrm{~mm}$. Values given as median \pm SE of median.

and Mennerick, 2007; Kole and Stuart, 2012), we investigated whether AP generation is particularly sensitive to $\left[\mathrm{HCO}_{3}^{-}\right]_{\mathrm{i}}$ regulation via KCNQ channels at the AIS. Previous studies have demonstrated APs generated in the soma or AIS exhibit subtle but measurable differences in AP waveforms (Meeks and Mennerick, 2007). To determine the origin of APs generated during current ramp protocols, the second derivative was calculated for each AP and was categorized as being either somatic or AIS in origin based on its distinct waveform (Fig. 2A). In our experiments, somatically generated APs preceded AIS generated APs during the ramp protocol and the number of $\mathrm{APs} / \mathrm{ramp}$ remained 


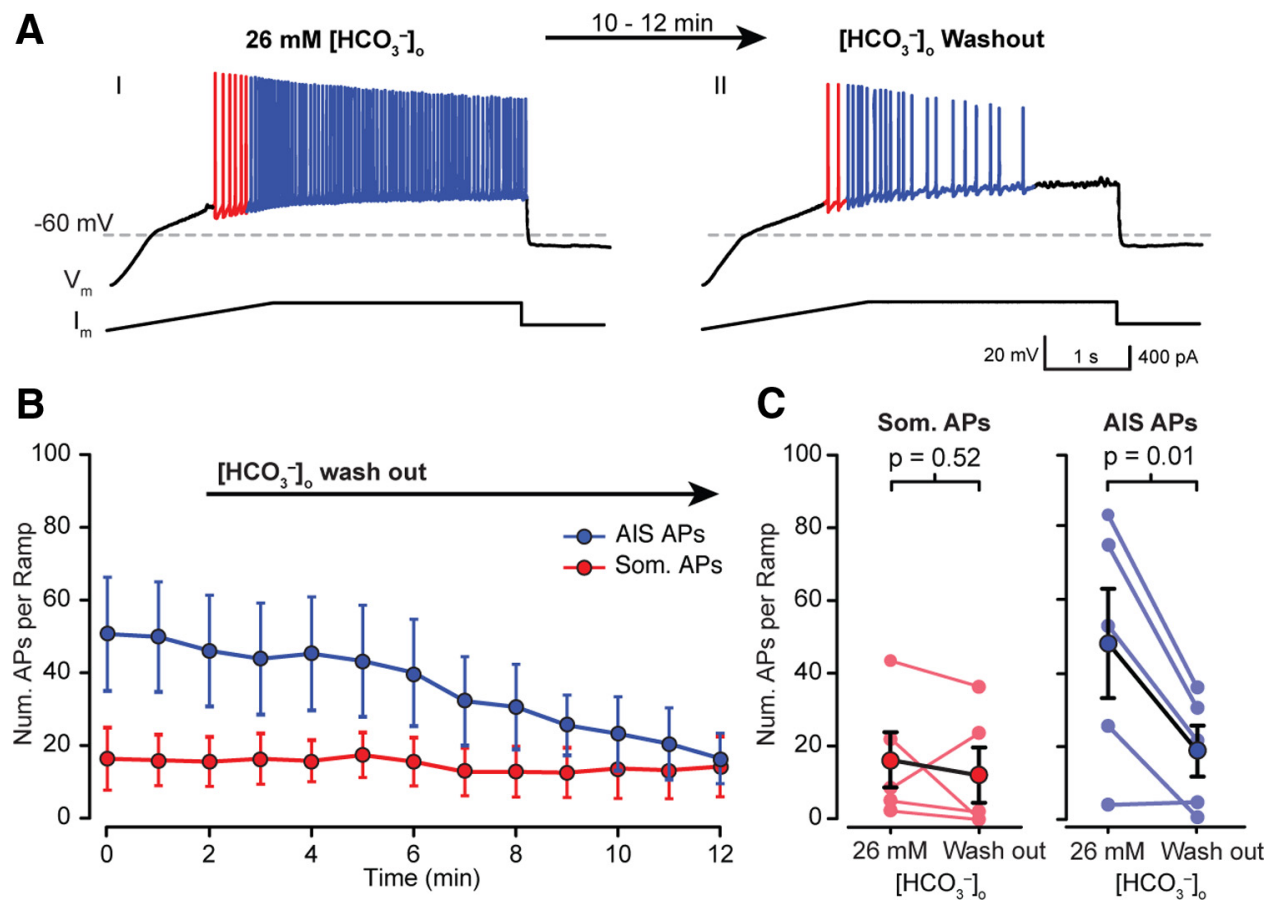

Figure 5. Wash out of extracellular $\mathrm{HCO}_{3}^{-}$regulate somatic and AIS AP generation. $\mathrm{Al}$, A sample $\mathrm{CA3} 3 \mathrm{PCs}$ exhibited robust $\mathrm{AP}$ generation under $0 \mathrm{~mm}\left[\mathrm{HCO}_{3}^{-}\right]_{\mathrm{p}}$ and $26 \mathrm{~mm}\left[\mathrm{HCO}_{3}^{-}\right]_{0}$ conditions, likely due to diffusion of extracellular $\mathrm{CO}_{2}$ through the membrane. AlI, Washing out $\left[\mathrm{HCO}_{3}^{-}\right]_{0}$ with HEPES-buffered aCSF significantly reduced the number of APs generated in response to the same current ramp protocol. $\boldsymbol{B}, \mathrm{PC}$ exhibit robust som and AIS AP generation in $0 \mathrm{~mm}\left[\mathrm{HCO}_{3}^{-}\right]_{\mathrm{p}}$ and $26 \mathrm{~mm}\left[\mathrm{HCO}_{3}^{-}\right]_{0^{\prime}}$ (time $=0 \mathrm{~min}$ ). $\boldsymbol{B}, \mathbf{C}$, AlS APs were significantly reduced after 10 min. of $\left[\mathrm{HCO}_{3}^{-}\right]_{0}$ wash out (minimum not reached after $10 \mathrm{~min}$ ), whereas som AP generation remained unchanged ( $\boldsymbol{B}, \mathrm{AIS}: p=0.02$, som: $p=0.25, n=5$, two-way ANOVA; $\boldsymbol{C}$, AIS: $p=0.52$, som: $p=0.01, n=5$, paired $t$ test).
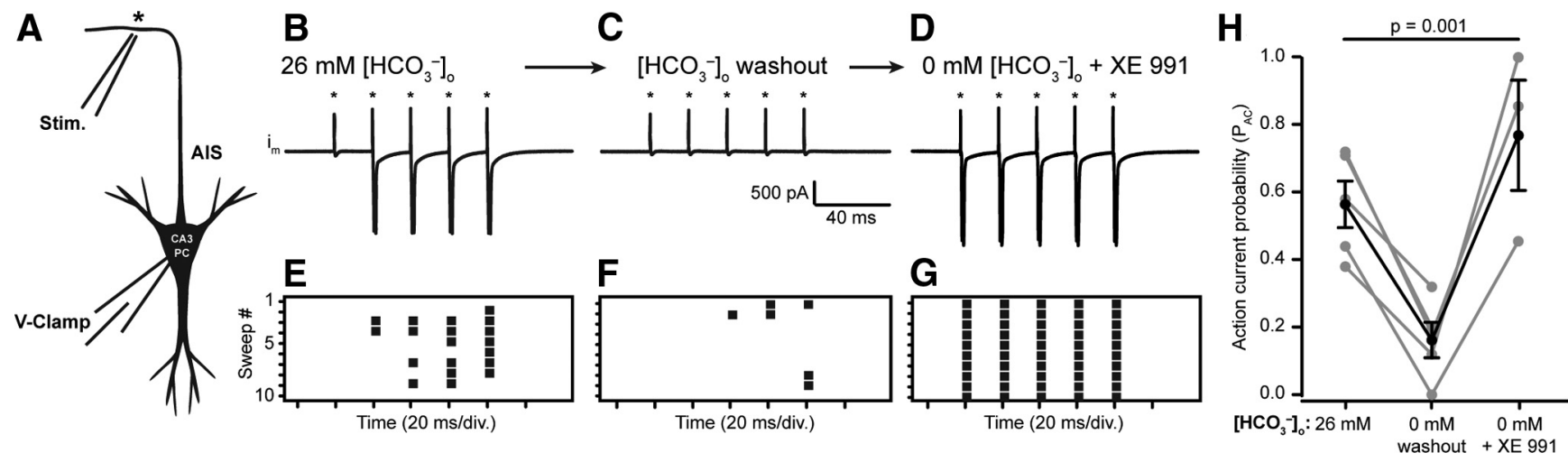

Figure 6. Wash out of extracellular $\mathrm{HCO}_{3}^{-}$reduces back-propagation of antidromic APs. $A$, Antidromic ACs were elicited by local axon stimulation ( $80 \mu \mathrm{s}$ pulse width, $\sim 250 \mu \mathrm{m}$ away from the soma) of visually identified $\mathrm{CA} 3 \mathrm{PCS} . \boldsymbol{B}, \boldsymbol{E}$, Trains of stimuli ( 5 stimuli, $50 \mathrm{~Hz}$, asterisks) evoked antidromic $\mathrm{ACs}$ recorded with $0 \mathrm{~mm}\left[\mathrm{HCO}_{3}^{-}\right]_{\mathrm{p}}$ and $26 \mathrm{~mm}\left[\mathrm{HCO}_{3}^{-}\right]_{0}$ and stimulus intensities were adjusted so that the $p_{\mathrm{AC}} \approx 0.5$ over 10 successive stimulus trains (raster plot, $\left.\boldsymbol{E}\right) . \boldsymbol{C}, \boldsymbol{F}$, Wash out of $\left[\mathrm{HCO}_{3}^{-}\right]_{0}$ significantly reduced the $p_{\mathrm{Ac},}$ illustrated with raster plots of ACs during 10 successive stimulus trains after $10-12 \min \left(n=5, p=0.009\right.$, one-way ANOVA, Dunnet's test). $\boldsymbol{D}$, $\boldsymbol{G}$, The $p_{\mathrm{AC}}$ recovered upon subsequent XE 991 wash in $(n=3, p=0.143$, one-way ANOVA, Dunnet's test). $\boldsymbol{H}$, Individual recordings indicated with gray lines, $p=0.001$, one-way ANOVA. Black lines represent mean $p_{\mathrm{AC}} \pm \mathrm{SEM}$.

stable during successive ramps (Fig. $2 \mathrm{~B}, \mathrm{C}$ ). When current ramps were performed with $26,13,6.5$, and $0 \mathrm{~mm}\left[\mathrm{HCO}_{3}^{-}\right]_{\mathrm{p}}$, we found that somatic and AIS AP generation was reduced in a dosedependent manner in ( $p<0.001$, two-way ANOVA; Fig. $3 A-C$, Fig. 4). Interestingly, decreasing the $\left[\mathrm{HCO}_{3}^{-}\right]_{\mathrm{p}}$ by half (26 to 13 $\mathrm{mM}$ ) dramatically reduced the median number of AIS APs per ramp $\left(26 \mathrm{~mm}\left[\mathrm{HCO}_{3}^{-}\right]_{\mathrm{p}}: 13 \pm 1\right.$ AIS APs/ramp vs $13 \mathrm{~mm}$ $\left[\mathrm{HCO}_{3}^{-}\right]_{\mathrm{p}}: 4 \pm 4$ AIS APs/ramp, median, $p=0.036$, MannWhitney; Fig. 4), whereas somatically generated APs were unaffected $\left(26 \mathrm{~mm}\left[\mathrm{HCO}_{3}^{-}\right]_{\mathrm{p}}: 22 \pm 4\right.$ somatic APs/ramp vs $13 \mathrm{~mm}$ $\left[\mathrm{HCO}_{3}^{-}\right]_{\mathrm{p}}: 19 \pm 5$ somatic APs/ramp, median, $p=0.788$, Mann-Whitney; Fig. 4). These data provide evidence that $\left[\mathrm{HCO}_{3}^{-}\right]_{\mathrm{i}}$ modulates AP generation in both cellular compart- ments and that AIS-generated APs are particularly sensitive to variations in $\left[\mathrm{HCO}_{3}^{-}\right]_{\mathrm{i}}$.

Extracellular bicarbonate regulates action potential generation by modulating KCNQ channel activation $\mathrm{CO}_{2}$ diffuses freely through the lipid bilayer according to the $\mathrm{CO}_{2} / \mathrm{HCO}_{3}^{-}$concentration gradient (Maren, 1967). Consequently, it should be possible to (locally) achieve an $\left[\mathrm{HCO}_{3}^{-}\right]_{\mathrm{i}}>$ $0 \mathrm{~mm}$ even with $0 \mathrm{~mm}\left[\mathrm{HCO}_{3}^{-}\right]_{\mathrm{p}}$ by changing $\left[\mathrm{HCO}_{3}^{-}\right]_{\mathrm{o}}$. This gives us the ability to modulate $\left[\mathrm{HCO}_{3}^{-}\right]_{\mathrm{i}}$ during an experiment simply by changing $\left[\mathrm{HCO}_{3}^{-}\right]_{0}$. To address this, whole-cell recordings were made from CA3 PCs with $26 \mathrm{~mm}\left[\mathrm{HCO}_{3}^{-}\right]_{\mathrm{o}}$, and $0 \mathrm{~mm}$ $\left[\mathrm{HCO}_{3}^{-}\right]_{\mathrm{p}}$ and were held for $\sim 10 \mathrm{~min}$ before beginning each 

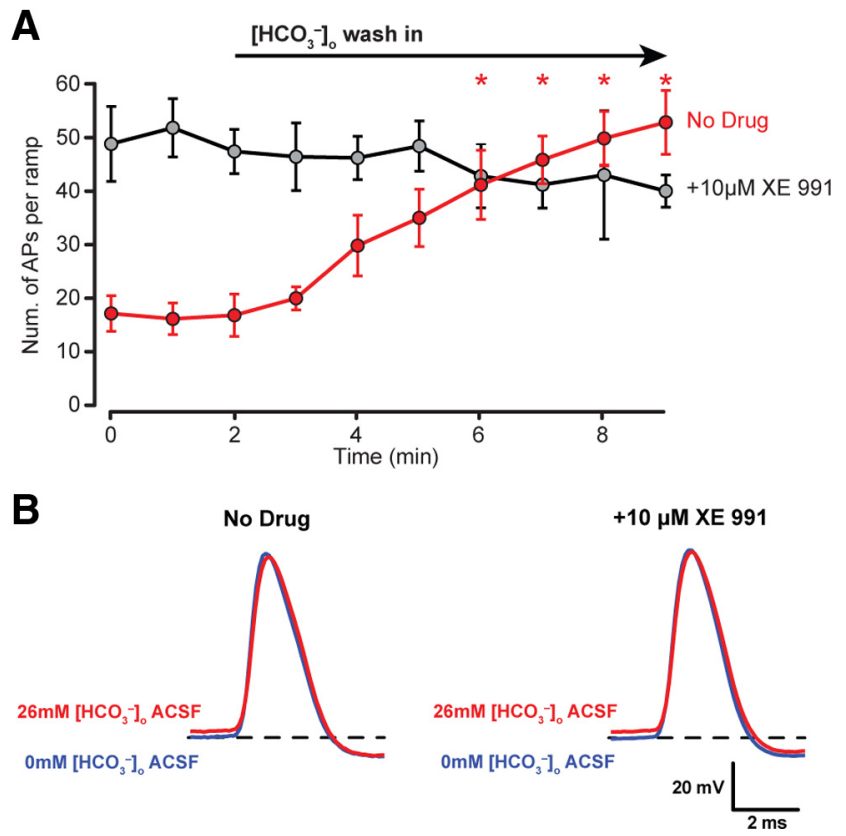

Figure 7. $\quad\left[\mathrm{HCO}_{3}^{-}\right]_{0}$ wash in increases $\mathrm{PC}$ excitability and does not affect the fast components of APs. $A$, The wash in of $26 \mathrm{~mm}\left[\mathrm{HCO}_{3}^{-}\right]_{0}$ under conditions of $0 \mathrm{~mm}\left[\mathrm{HCO}_{3}^{-}\right]_{p}$ increases AP firing (red, No Drug; $p<0.001$, RM two-way ANOVA), but no such effect is seen when the KCNQ selective antagonist XE 991 is present (gray, $+10 \mu \mathrm{m}$ XE 991; $p=0.943$, RM two-way ANOVA). B, Wash in of $26 \mathrm{~mm}\left[\mathrm{HCO}_{3}^{-}\right]_{0}$ aCSF does not alter the fast AP components (AP amplitude, half-width, and fAHP amplitude) both in the absence (№ Drug) and in the presence of the XE 991 ( $+10 \mu \mathrm{M}$ XE 991, $p>0.05$, RM two-way ANOVA).

Table 3. Fast AP properties

\begin{tabular}{lllll}
\hline $\left.\mathrm{HCO}_{3}^{-}\right]_{0}(\mathrm{mM})$ & 0 & 26 & 0 & 26 \\
$\mathrm{XE} 991(10 \mu \mathrm{M})$ & - & - & + & + \\
Threshold $(\mathrm{mV})$ & $-40 \pm 2$ & $-38 \pm 2^{*}$ & $-43 \pm 1$ & $-41 \pm 1^{*}$ \\
AP amplitude $(\mathrm{mV})$ & $75 \pm 3$ & $71 \pm 3$ & $70 \pm 2$ & $67 \pm 3$ \\
Half-width $(\mu \mathrm{s})$ & $800 \pm 33$ & $858 \pm 47$ & $866 \pm 55$ & $878 \pm 68$ \\
fAHP amplitude $(\mathrm{mV})^{a}$ & $7.8 \pm 0.5$ & $8.4 \pm 0.5$ & $6.3 \pm 1.4$ & $6.1 \pm 1.5$ \\
$n$ & 6 & & 5 &
\end{tabular}

AP amplitude, half-width, and fAHP properties were unaffected by wash-in of $\left[\mathrm{HCO}_{3}^{-}\right]_{0}$ or $\mathrm{KCNQ}$ channel block by XE 991 ( $p>0.05$ for $\mathrm{HCO}_{3}^{-}$effect, XE 991 effect and interaction, two-way RM ANOVA). AP thresholds were $\sim 2 \mathrm{mV}$ higher in $26 \mathrm{mM}\left[\mathrm{HCO}_{3}^{-}\right]_{0}$ both with and without XE 991 ( $p=0.04$ for $\mathrm{HCO}_{3}^{-}$; effect and $p>0.05$ for XE 991 effect and interaction, two-way RM ANOVA). Values are mean \pm SEM.

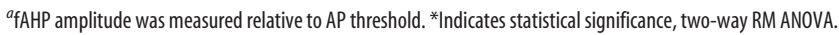

experiment to dialyze each cell with the pipette solution. Under these conditions, current ramp protocols generated robust APs (median $=60 \pm 8$ APs/ramp; Fig. $5 A$ ), with most APs generated at the AIS (blue colored APs). Subsequent $\left[\mathrm{HCO}_{3}^{-}\right]_{\mathrm{o}}$ wash out significantly reduced the number of AIS APs/ramp (26 mM $\left[\mathrm{HCO}_{3}^{-}\right]_{\mathrm{o}}: 48 \pm 15$ AIS APs/ramp; $0 \mathrm{~mm}\left[\mathrm{HCO}_{3}^{-}\right]_{\mathrm{o}}: 19 \pm 7 \mathrm{AIS}$ APs/ramp, mean \pm SEM, $p<0.001$, R.M. two-way ANOVA; Fig. $5 B, C$ ) while the number of somatically generated APs was unaffected $\left(26 \mathrm{~mm}\left[\mathrm{HCO}_{3}^{-}\right]_{\mathrm{o}}: 16 \pm 7\right.$ somatic APs/ramp; $0 \mathrm{~mm}$ $\left[\mathrm{HCO}_{3}^{-}\right]_{\mathrm{o}}: 12 \pm 7$ somatic APs/ramp, mean $\pm \mathrm{SEM}, p>0.999$, RM two-way ANOVA; Fig. $5 \mathrm{~B}, \mathrm{C})$. No effect of $\left[\mathrm{HCO}_{3}^{-}\right]_{\mathrm{o}}$ was observed when the experiments were repeated in the presence of XE 991 (data not shown).

To further evaluate the effect of reduced $\left[\mathrm{HCO}_{3}^{-}\right]_{\mathrm{i}}$ on AP generation at the AIS, we performed voltage-clamp recordings on $\mathrm{CA} 3 \mathrm{PCs}$ with $0 \mathrm{~mm}\left[\mathrm{HCO}_{3}^{-}\right]_{\mathrm{p}}$ and $26 \mathrm{~mm}\left[\mathrm{HCO}_{3}^{-}\right]_{\mathrm{o}}$. Recorded neurons were visualized by filling with AlexaFluor 488, and antidromic action currents were generated by local axon stimulation ( $\sim 250 \mu \mathrm{m}$ away from the soma; Fig. $6 A$ ). Stimulation intensity
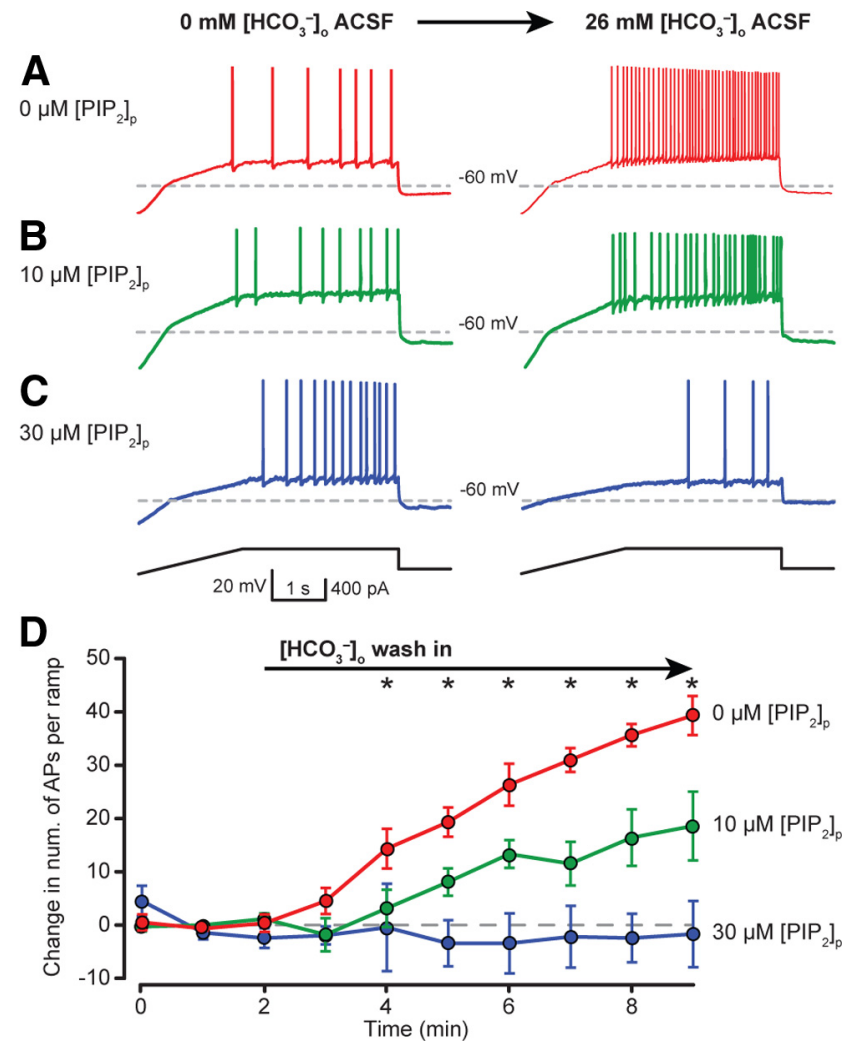

Figure 8. $\left.\quad \mathrm{HCO}_{3}^{-}\right]$regulates neuronal excitability by modulating intracellular $\mathrm{PIP}_{2}$ concentration. $\mathrm{PC}$ s exhibited dampened excitability in HEPES-buffered $\left(0 \mathrm{~mm}\left[\mathrm{HCO}_{3}^{-}\right]_{0}\right)$ aCSF, and wash in of $26 \mathrm{~mm}\left[\mathrm{HCO}_{3}^{-}\right]_{0}$ significantly increased the number of $A P s / \operatorname{ramp}(A, D$, red). Increase in $P C$ excitability during $26 \mathrm{~mm}\left[\mathrm{HCO}_{3}^{-}\right]_{0}$ wash in was dampened or absent when $10 \mu \mathrm{m}(\boldsymbol{B}, \boldsymbol{D}$, green) or $30 \mu \mathrm{M} \mathrm{PIP}_{2}(\boldsymbol{C}, \boldsymbol{D}$, blue) was included in the patch solution, respectively. $\boldsymbol{D}$, Current ramp protocol assessed relative neuronal excitability during transition from 0 to $26 \mathrm{~mm}\left[\mathrm{HCO}_{3}^{-}\right]_{0}$. Recordings made with $0 \mathrm{~mm}\left[\mathrm{HCO}_{3}^{-}\right]_{\mathrm{p}}$ pipette solution and $0 \mu \mathrm{M} \mathrm{PIP}$ (red) showed a robust increase in the number of APs/ramp during $26 \mathrm{~mm}\left[\mathrm{HCO}_{3}^{-}\right]_{0}$ wash in. Including 10 (green) or 30 (blue) $\mu \mathrm{M}$ PIP ${ }_{2}$ to the patch solution dampened or blocked the increase in neuronal excitability, respectively, upon $26 \mathrm{~mm}\left[\mathrm{HCO}_{3}^{-}\right]_{0}$ wash in (mean $\pm \mathrm{SEM}$ ). *Indicates statistically significant post hoc paired tests with correction for multiple comparisons, RM two-way ANOVA.

was adjusted to produce $\sim 0.5$ probability of antidromic action currents $\left(p_{\mathrm{AC}}\right)$ in response to stimulus trains $(5$ stimuli, $50 \mathrm{~Hz}$; Fig. $6 \mathrm{C}$ ). When $\left[\mathrm{HCO}_{3}^{-}\right]_{\mathrm{o}}$ was washed out with HEPES-buffered aCSF, $\mathrm{pH} 7.4$, the $p_{\mathrm{AC}}$ was dramatically reduced from $0.56 \pm 0.10$ in $26 \mathrm{mM}\left[\mathrm{HCO}_{3}^{-}\right]_{\mathrm{o}}$ to $0.16 \pm 0.05$ in $0 \mathrm{mM}^{2}\left[\mathrm{HCO}_{3}^{-}\right]_{\mathrm{o}}$ (mean \pm SEM, $p=0.009, n=5$, one-way ANOVA; Fig. $6 B, C, E, F, H)$. The $p_{\text {AC }}$ recovered to $0.77 \pm 0.16$ upon subsequent XE 991 (10 $\mu \mathrm{M})$ application after $\left[\mathrm{HCO}_{3}^{-}\right]_{\mathrm{o}}$ washout $(n=3, p=0.142$, one-way ANOVA, Fig. $6 D, G, H)$. These data support the hypothesis that reductions in $\left[\mathrm{HCO}_{3}^{-}\right]_{\mathrm{i}}$ can reduce the probability of AP generation at the AIS though a KCNQ channeldependent mechanism.

Previous studies have demonstrated that changes in $\left[\mathrm{HCO}_{3}^{-}\right]_{\mathrm{o}}$ can alter intracellular $\mathrm{pH}$ and alter neuronal excitability (Schwiening and Boron, 1994; Bonnet et al., 1998). In our experiments, the intracellular solution used in our recordings was buffered to $\mathrm{pH}$ 7.3-7.35 with $10 \mathrm{~mm}$ HEPES. Although $10 \mathrm{~mm}$ HEPES is typically used to set the $\mathrm{pH}$ of pipette solutions during whole-cell recordings, previous reports have demonstrated that $10 \mathrm{mM}$ HEPES may not provide sufficient buffering capacity during periods of high neuronal activity or in the absence of $\mathrm{HCO}_{3}^{-}$-dependent intraneuronal buffering (Schwiening and Boron, 1994; Trapp et al., 1996). Therefore, we sought to determine to what extent fluctuations in intraneuronal $\mathrm{pH}$ 


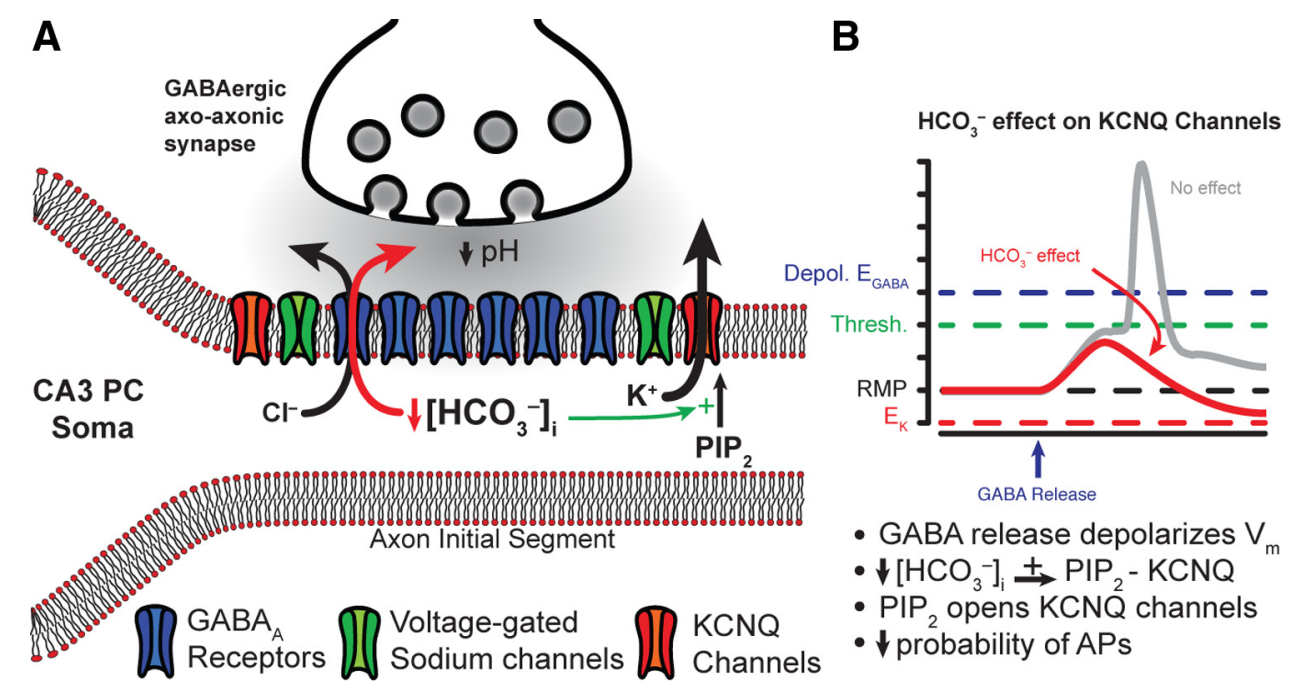

Figure 9. Proposed function of $\mathrm{HCO}_{3}^{-}$-dependent regulation of KCNQ channels at the AIS. $A$, Schematic representation of $\mathrm{CA} 3 \mathrm{PC}$ axon initial segment and axo-axonic $\mathrm{GABAergic}$ synapse. $B$, With a depolarized $\mathrm{E}_{G A B A}$, activation of synaptic $G_{A B A_{A}}$ receptors $\left(G_{A B A} R S\right)$ during synaptic $G A B A$ release would result in membrane depolarization leading to an increased $A P$ firing probability at the AIS (gray trace). However, local depletion of $\left[\mathrm{HCO}_{3}^{-}\right]_{i}$ through $\mathrm{GABA}_{\mathrm{A}} \mathrm{Rs}$ facilitates PIP, $-\mathrm{KCNQ}$ channel interactions and consequently KCNQ channel activity (green arrow). Enhanced KCNQ channel activation dampens excitability at the AIS and reduces AP probability, thus ensuring an inhibitory effect of axoaxonic cell activation despite a depolarized $\mathrm{E}_{\mathrm{GABA}}$ (red trace).

may contribute to the excitability of PCs in response to our current ramp protocol. We recorded from CA3 PCs in $0 \mathrm{~mm}\left[\mathrm{HCO}_{3}^{-}\right]_{\mathrm{o}}$ using intracellular solutions buffered with $50 \mathrm{~mm}$ HEPES and the $\mathrm{pH}$ set to either 7.0 or 7.6. Current ramp protocols performed at these halved or doubled $\left[\mathrm{H}^{+}\right]$relative to our controls $(\mathrm{pH}=7.3)$ revealed no significant effect of intraneuronal $\mathrm{pH}$ on the number of APs generated per ramp ( $\mathrm{pH} 7.0$ : $14 \pm 3 \mathrm{vs} \mathrm{pH} 7.6: 14 \pm 4 \mathrm{APs} / \mathrm{ramp}$, median, $n=6$ and 5, respectively, $p>0.99$, Mann-Whitney). These data demonstrate that $\mathrm{pH}$ fluctuations between 7.0 and 7.6 do not significantly affect CA3 PC excitability in our experimental conditions, and therefore the observed changes in excitability are likely to be directly caused by changes in $\mathrm{HCO}_{3}^{-}$.

$\mathrm{PIP}_{2}$ prevents $\mathrm{HCO}_{3}^{-}$-mediated increase in PC excitability KCNQ channels are subject to a number of regulatory pathways and can be controlled via $\mathrm{Ca}^{2+}$, diacylgycerol, and Src tyrosine kinase, though primary control runs through the phosphoinositide-phospholipase $\mathrm{C}$ cycle via $\mathrm{PIP}_{2}$ (Delmas and Brown, 2005; Suh and Hille, 2008; Andrade et al., 2012; Telezhkin et al., 2012). Intracellular $\mathrm{PIP}_{2}$ facilitates KCNQ channel opening in a dose-dependent manner and recent findings demonstrated that $\mathrm{PIP}_{2}$ is required to couple the voltage sensing domain to pore opening (Zhang et al., 2003; Telezhkin et al., 2012; Zaydman et al., 2013). Consequently, we tested the hypothesis that $\mathrm{HCO}_{3}^{-}$ regulates KCNQ channel activation through intracellular $\mathrm{PIP}_{2}$.

We first tested to see whether CA3 PCs would exhibit an increase in excitability when switching from 0 to $26 \mathrm{mM}\left[\mathrm{HCO}_{3}^{-}\right]_{\mathrm{o}}$, analogous to the previous $\left[\mathrm{HCO}_{3}^{-}\right]_{\mathrm{o}}$ wash out experiments. Whole-cell current-clamp recordings from CA3 PCs were performed in $0 \mathrm{~mm}\left[\mathrm{HCO}_{3}^{-}\right]_{\mathrm{o}}$ and $0 \mathrm{mM}\left[\mathrm{HCO}_{3}^{-}\right]_{\mathrm{p}}$ and each recording was held for $\sim 10$ min before beginning the experiment to allow adequate dialysis of the PC with the pH buffered (7.3) internal solution. Wash in of $26 \mathrm{~mm}\left[\mathrm{HCO}_{3}^{-}\right]_{\mathrm{o}}$ aCSF elicited a robust increase in PC excitability from $17 \pm 3$ APs/ramp to $53 \pm$ $6 \mathrm{APs} /$ ramp after $10 \mathrm{~min}$ of wash in (mean $\pm \mathrm{SEM}, n=6, p<$ 0.01 , two-way RM ANOVA; Fig. $7 A$, red trace). When $\left[\mathrm{HCO}_{3}^{-}\right]_{\mathrm{o}}$ wash in experiments were repeated in the presence of $10 \mu \mathrm{M} \mathrm{XE}$ 991, PCs exhibited strong AP generation in $0 \mathrm{~mm}\left[\mathrm{HCO}_{3}^{-}\right]_{\mathrm{o}}$ aCSF, with an average of $49 \pm 7 \mathrm{APs} / \mathrm{ramp}$ (Fig. $7 \mathrm{~A}$, gray trace). Wash in of $26 \mathrm{~mm}\left[\mathrm{HCO}_{3}^{-}\right]_{\mathrm{o}}$ aCSF, did not significantly increase CA3 PC excitability $\left(0 \mathrm{~mm}\left[\mathrm{HCO}_{3}^{-}\right]_{\mathrm{o}}: 49 \pm 7 \mathrm{APs} / \mathrm{ramp}\right.$ to $26 \mathrm{~mm}$ $\left[\mathrm{HCO}_{3}^{-}\right]_{\mathrm{o}}: 40 \pm 3 \mathrm{APs} / \mathrm{ramp}, n=5, p=0.943$, two-way RM ANOVA, Fig. $7 A$, gray trace).

To confirm that $\left[\mathrm{HCO}_{3}^{-}\right]_{\mathrm{o}}$ does not affect other conductances underlying AP generation, fast AP waveform properties (i.e., amplitude, half-width, and fAHP) were assessed before and after 26 $\mathrm{mM}\left[\mathrm{HCO}_{3}^{-}\right]_{\mathrm{o}}$ wash in and in the presence of XE 991 (Fig. 7B; Table 3). No significant effects were observed on AP amplitude, half-width, or fHAP before or after $26 \mathrm{~mm}\left[\mathrm{HCO}_{3}^{-}\right]_{\mathrm{o}}$ wash in with or without XE 991, suggesting that no other major conductances underlying AP generation are affected by $\mathrm{HCO}_{3}^{-}$other than KCNQ channels ( $p>0.05$ for $\left[\mathrm{HCO}_{3}^{-}\right]_{\mathrm{o}}$ effect, XE 991 effect, and interaction, RM two-way ANOVA; Fig. 7B; Table 3). Interestingly, $\mathrm{AP}$ threshold was $\sim 2 \mathrm{mV}$ higher in $26 \mathrm{mM}\left[\mathrm{HCO}_{3}^{-}\right]_{\mathrm{o}}$ whether or not XE 991 was present, but the biological significance of this finding is unclear at this time ( $p$ values: $\left[\mathrm{HCO}_{3}^{-}\right]_{\mathrm{o}}$ effect $=$ $0.04, \mathrm{XE} 991$ effect $=0.11$, interaction $=0.85$, RM two-way ANOVA; Fig. 7B; Table 3).

Having established that $26 \mathrm{~mm}\left[\mathrm{HCO}_{3}^{-}\right]_{\mathrm{o}}$ wash in could dramatically increase the excitability of CA3 PCs and that this effect was dependent on KCNQ channels, we sought to determine whether the $\mathrm{HCO}_{3}^{-}$dependent increase in neuronal excitability could be due to modulation of intracellular PIP 2 . Whole-cell current-clamp recordings from CA3 PCs were performed in 0 $\mathrm{mM}\left[\mathrm{HCO}_{3}^{-}\right]_{\mathrm{o}}$ and $0 \mathrm{~mm}\left[\mathrm{HCO}_{3}^{-}\right]_{\mathrm{p}}$ containing 0,10 or $30 \mu \mathrm{M} \mathrm{PIP}$ $\left(\left[\mathrm{PIP}_{2}\right]_{\mathrm{p}}\right)$ and current ramps were used to assess PC excitability in $0 \mathrm{mM}\left[\mathrm{HCO}_{3}^{-}\right]_{\mathrm{o}}$ and in $26 \mathrm{~mm}\left[\mathrm{HCO}_{3}^{-}\right]_{\mathrm{o}}$. Wash in of $26 \mathrm{~mm}$ $\left[\mathrm{HCO}_{3}^{-}\right]_{\mathrm{o}}$ with $0 \mu \mathrm{M}\left[\mathrm{PIP}_{2}\right]_{\mathrm{p}}$ significantly increased the number of APs/ramp $(+40 \pm 4$ APs/ramp, $n=6 ; p<0.001$, two-way ANOVA; Fig. $8 A, D)$. In contrast, including 10 or $30 \mu \mathrm{M}\left[\mathrm{PIP}_{2}\right]$ in the pipet solution dampened or completely occluded the increase in PC excitability during $26 \mathrm{~mm}\left[\mathrm{HCO}_{3}^{-}\right]_{\mathrm{o}}$ wash in, respectively $\left(10 \mu \mathrm{M}\left[\mathrm{PIP}_{2}\right]_{\mathrm{p}}:+19 \pm 6 \mathrm{APs} / \mathrm{ramp}, n=6,30 \mu \mathrm{M}\left[\mathrm{PIP}_{2}\right]_{\mathrm{p}}:-2 \pm\right.$ 5 APs/ramp, $n=4 ; p<0.001$, two-way ANOVA; Fig. $8 B-D$ ). Therefore, $\left[\mathrm{HCO}_{3}^{-}\right]$appears to inhibit KCNQ channel activation by interfering with the actions of $\mathrm{PIP}_{2}$ on the channel, resulting in increased neuronal excitability. 


\section{Discussion}

Here we describe a novel mechanism whereby $\left[\mathrm{HCO}_{3}^{-}\right]_{\mathrm{i}}$ profoundly modulates the excitability of hippocampal CA3 pyramidal neurons through KCNQ channel regulation. Moreover, $\mathrm{HCO}_{3}^{-}$may regulate KCNQ channels by preventing $\mathrm{PIP}_{2}$ from activating the channels, a fundamental mechanism previously shown to exert a strong control over KCNQ channel opening. Our findings are the first demonstration of a direct regulation of neuronal excitability by $\left[\mathrm{HCO}_{3}^{-}\right]_{\mathrm{i}}$, independent of $\mathrm{pH}$.

Discovering the molecular identity of the $\mathrm{HCO}_{3}^{-}$sensor and of the precise pathway leading to interference with the $\mathrm{PIP}_{2}$ dependent KCNQ channel modulation will require further extensive studies. To date, only two signaling molecules are known to be directly activated by $\mathrm{HCO}_{3}^{-}$independently of $\mathrm{pH}$ : guanylyl cyclase-D (GC-D; Guo et al., 2009; Luo et al., 2009) and a soluble form of adenylyl cyclase (sAC; Chen et al., 2000; Tresguerres et al., 2010). GC-D has been described to play a role in the olfactory detection of $\mathrm{CO}_{2}$ in some species and has only been found in olfactory bulb neurons (Fülle et al., 1995; Scott, 2011). Therefore, GC-D is unlikely to play a role in regulating KCNQ channels in our results. Soluble adenylyl cyclase has been shown to directly sense $\mathrm{HCO}_{3}^{-}$in a $\mathrm{pH}$-independent manner, resulting in an increase in local cAMP levels and protein kinase A (PKA) activation (Chen et al., 2000). Recent studies have demonstrated strong expression of sAC in astrocytes, where it modulates astrocyteneuron metabolic coupling, and immunoelectron microscopy has also revealed the presence of sAC in neurons (Choi et al., 2012; Chen et al., 2013). Importantly, the rate-limiting enzyme for $\mathrm{PIP}_{2}$ generation, PIP5 kinase, is strongly inhibited by phosphorylated PKA (Park et al., 2001; Delmas and Brown, 2005). Thus, sAC may be an attractive candidate as the molecular detector that couples $\mathrm{HCO}_{3}^{-}$to KCNQ channel modulation in CA3 PCs. However, activation of PKA has also been shown to have a direct long-lasting potentiating effect on Kv7/KCNQ channels (Wu et al., 2008). Considering these dual and potentially opposing effects of PKA activation on Kv7/KCNQ channels, the identification of PKA as the downstream effector of $\mathrm{HCO}_{3}^{-}$will require extensive future studies.

The reduction in $\mathrm{KCNQ}$ channel activity by $\mathrm{HCO}_{3}^{-}$could be significant in the context of GABAergic innervation of the AIS by chandelier or axoaxonic cells. The excitatory or inhibitory nature of this innervation is highly controversial. Anatomical studies have demonstrated the absence of the $\mathrm{Cl}^{-}$extruding transporter KCC2 and the presence of the $\mathrm{Cl}^{-}$importing transporter NKCC1 at the AIS, leading to a depolarizing $\mathrm{E}_{\mathrm{GABA}}$ (by $\sim 20 \mathrm{mV}$ ) relative to somatic and dendritic compartments (Khirug et al., 2008; Woodruff et al., 2009; Báldi et al., 2010) and possibly resulting GABAergic excitation (Fig. 9; Szabadics et al., 2006). Other studies, however, have provided evidence for GABAergic inhibition by AIS-innervating interneurons (Glickfeld et al., 2009). The inhibitory nature of the GABAergic input onto the AIS, regardless of the relationship between $\mathrm{E}_{\mathrm{GABA}}$ and the membrane potential, may be further supported by our present findings. Synaptic $\mathrm{GABA}_{\mathrm{A}}$ receptors are permeable to $\mathrm{HCO}_{3}^{-}$, with a permeability ratio of $\mathrm{P}_{\mathrm{HCO} 3}^{-} / \mathrm{P}_{\mathrm{Cl}}^{-}=0.2$ (Kaila, 1994). At the synapse, $\mathrm{E}_{\mathrm{HCO} 3} \approx$ $-10 \mathrm{mV}$ due to active intracellular $\mathrm{HCO}_{3}^{-}$regulation (Kaila, 1994). Consequently, $\mathrm{GABA}_{\mathrm{A}}$ receptor activation at normal resting membrane potential $(\sim-70 \mathrm{mV})$ results in $\mathrm{HCO}_{3}^{-}$efflux through the channel and local decreases in $\left[\mathrm{HCO}_{3}^{-}\right]_{\mathrm{i}}$. However, during heavy synaptic transmission, the outward driving force for $\mathrm{HCO}_{3}^{-}$may be even larger than $\sim 60 \mathrm{mV}$ due to acidification of the synaptic cleft. The luminal $\mathrm{pH}$ of synaptic vesicles is $\sim 5.5$
(Miesenböck et al., 1998), and even single-vesicle release (e.g., miniature IPSCs) has been shown to acidify the synaptic cleft at GABAergic synapses (Dietrich and Morad, 2010). Therefore, periods of heavy GABAergic activity (Dugladze et al., 2012) may cause considerable synaptic cleft acidification at axoaxonic synapses, further decreasing the local $\left[\mathrm{HCO}_{3}^{-}\right]_{\mathrm{o}}$ in the cleft and increasing the $\mathrm{HCO}_{3}^{-}$driving force $\left(\Delta \mathrm{E}_{\mathrm{HCO} 3} \sim 60 \mathrm{mV} / \mathrm{pH}\right.$ unit). Given the large surface-to-volume ratio of the AIS and its low intracellular volume, the rapid outflow of $\mathrm{HCO}_{3}^{-}$could conceivably cause a sharp drop in local $\left[\mathrm{HCO}_{3}^{-}\right]_{\mathrm{i}}$.

Previous reports have demonstrated that $\mathrm{HCO}_{3}^{-}$efflux through the GABA receptor promotes the accumulation of intracellular $\mathrm{Cl}^{-}$, resulting in decreased GABAergic efficacy during periods of high GABAergic activation (Staley et al., 1995; Kaila et al., 1997). Additionally, the activity of neuronal carbonic anhydrases (II and VII) was recently shown to be required for this $\mathrm{HCO}_{3}^{-}$-dependent intracellular $\mathrm{Cl}^{-}$accumulation (Ruusuvuori et al., 2013), providing more evidence for a strong interplay between $\mathrm{HCO}_{3}^{-}$and GABA receptor efficacy. Given the data presented in this study, it is possible that a large drop in local $\left[\mathrm{HCO}_{3}^{-}\right]_{\mathrm{i}}$ at the AIS during heavy GABAergic activity could facilitate local KCNQ channel activity and greatly reduce AP generation despite the accumulation of intracellular $\mathrm{Cl}^{-}$and the reduction of GABAergic efficacy (Fig. 9). Although this hypothesis will require further investigation, such a mechanism would ensure that the GABAergic input to the AIS is predominantly inhibitory regardless of $\mathrm{E}_{\mathrm{GABA}}$.

\section{References}

Andrade R, Foehring RC, Tzingounis AV (2012) The calcium-activated slow AHP: cutting through the Gordian knot. Front Cell Neurosci 6:47. CrossRef Medline

Báldi R, Varga C, Tamás G (2010) Differential distribution of KCC2 along the axo-somato-dendritic axis of hippocampal principal cells. Eur J Neurosci 32:1319-1325. CrossRef Medline

Bonnet U, Wiemann M, Bingmann D (1998) CO2/HCO3--withdrawal from the bath medium of hippocampal slices: biphasic effect on intracellular $\mathrm{pH}$ and bioelectric activity of CA3-neurons. Brain Res 796:161-170. CrossRef Medline

Casey JR, Grinstein S, Orlowski J (2010) Sensors and regulators of intracellular pH. Nat Rev Mol Cell Biol 11:50-61. CrossRef Medline

Chen J, Martinez J, Milner TA, Buck J, Levin LR (2013) Neuronal expression of soluble adenylyl cyclase in the mammalian brain. Brain Res 1518: 1-8. CrossRef Medline

Chen Y, Cann MJ, Litvin TN, Iourgenko V, Sinclair ML, Levin LR, Buck J (2000) Soluble adenylyl cyclase as an evolutionarily conserved bicarbonate sensor. Science 289:625-628. CrossRef Medline

Chesler M, Kaila K (1992) Modulation of pH by neuronal activity. Trends Neurosci 15:396-402. CrossRef Medline

Choi HB, Gordon GR, Zhou N, Tai C, Rungta RL, Martinez J, Milner TA, Ryu JK, McLarnon JG, Tresguerres M, Levin LR, Buck J, MacVicar BA (2012) Metabolic communication between astrocytes and neurons via bicarbonate-responsive soluble adenylyl cyclase. Neuron 75:10941104. CrossRef Medline

Cooper EC (2011) Made for "anchorin”: Kv7.2/7.3 (KCNQ2/KCNQ3) channels and the modulation of neuronal excitability in vertebrate axons. Semin Cell Dev Biol 22:185-192. CrossRef Medline

Delmas P, Brown DA (2005) Pathways modulating neural KCNQ/M (Kv7) potassium channels. Nat Rev Neurosci 6:850-862. CrossRef Medline

Dietrich CJ, Morad M (2010) Synaptic acidification enhances GABAA signaling. J Neurosci 30:16044-16052. CrossRef Medline

Dugladze T, Schmitz D, Whittington MA, Vida I, Gloveli T (2012) Segregation of axonal and somatic activity during fast network oscillations. Science 336:1458-1461. CrossRef Medline

Fry CH, Poole-Wilson PA (1981) Effects of acid-base changes on excitationcontraction coupling in guinea-pig and rabbit cardiac ventricular muscle. J Physiol-London 313:141-160. Medline

Fülle HJ, Vassar R, Foster DC, Yang RB, Axel R, Garbers DL (1995) A recep- 
tor guanylyl cyclase expressed specifically in olfactory sensory neurons. Proc Natl Acad Sci U S A 92:3571-3575. CrossRef Medline

Glickfeld LL, Roberts JD, Somogyi P, Scanziani M (2009) Interneurons hyperpolarize pyramidal cells along their entire somatodendritic axis. Nat Neurosci 12:21-23. CrossRef Medline

Greenwald I (1941) The dissociation of calcium and magnesium carbonates and bicarbonates. J Biol Chem 141:789-796.

Gu N, Vervaeke K, Hu H, Storm JF (2005) Kv7/KCNQ/M and HCN/h, but not KCa2/SK channels, contribute to the somatic medium afterhyperpolarization and excitability control in CA1 hippocampal pyramidal cells. J Physiol 566:689-715. CrossRef Medline

Gu N, Hu H, Vervaeke K, Storm JF (2008) SK (KCa2) channels do not control somatic excitability in CA1 pyramidal neurons but can be activated by dendritic excitatory synapses and regulate their impact. J Neurophysiol 100:2589-2604. CrossRef Medline

Guo D, Zhang JJ, Huang XY (2009) Stimulation of guanylyl cyclase-D by bicarbonate. Biochemistry 48:4417-4422. CrossRef Medline

Hablitz JJ, Heinemann U (1987) Extracellular K+ and Ca2+ changes during epileptiform discharges in the immature rat neocortex. Brain Res 433:299-303. Medline

Hu H, Vervaeke K, Storm JF (2007) M-channels (Kv7/KCNQ channels) that regulate synaptic integration, excitability, and spike pattern of CA1 pyramidal cells are located in the perisomatic region. J Neurosci 27:18531867. CrossRef Medline

Jacobson RL, Langmuir D (1974) Dissociation-constants of calcite and Cahco3+ from 0 to $50^{\circ} \mathrm{C}$. Geochim Cosmochim Acta 38:301-318. CrossRef

Jungas RL (2006) Best literature values for the pK of carbonic and phosphoric acid under physiological conditions. Anal Biochem 349:1-15. CrossRef Medline

Kaila K (1994) Ionic basis of GABAA receptor channel function in the nervous system. Prog Neurobiol 42:489-537. CrossRef Medline

Kaila K, Lamsa K, Smirnov S, Taira T, Voipio J (1997) Long-lasting GABA-mediated depolarization evoked by high-frequency stimulation in pyramidal neurons of rat hippocampal slice is attributable to a network-driven, bicarbonate-dependent K+ transient. J Neurosci 17: 7662-7672. Medline

Khirug S, Yamada J, Afzalov R, Voipio J, Khiroug L, Kaila K (2008) GABAergic depolarization of the axon initial segment in cortical principal neurons is caused by the $\mathrm{Na}-\mathrm{K}-2 \mathrm{Cl}$ cotransporter NKCC1. J Neurosci 28: 4635-4639. CrossRef Medline

Klinger F, Gould G, Boehm S, Shapiro MS (2011) Distribution of $\mathrm{M}$-channel subunits KCNQ2 and KCNQ3 in rat hippocampus. Neuroimage 58:761-769. CrossRef Medline

Kole MH, Stuart GJ (2012) Signal processing in the axon initial segment. Neuron 73:235-247. CrossRef Medline

Luo M, Sun L, Hu J (2009) Neural detection of gases-carbon dioxide, oxygen-in vertebrates and invertebrates. Curr Opin Neurobiol 19:354361. CrossRef Medline

Maren TH (1967) Carbonic anhydrase: chemistry, physiology, and inhibition. Physiol Rev 47:595-781. Medline

Meeks JP, Mennerick S (2007) Action potential initiation and propagation in CA3 pyramidal axons. J Neurophysiol 97:3460-3472. CrossRef Medline

Meeks JP, Jiang X, Mennerick S (2005) Action potential fidelity during nor$\mathrm{mal}$ and epileptiform activity in paired soma-axon recordings from rat hippocampus. J Physiol 566:425-441. CrossRef Medline

Miesenböck G, De Angelis DA, Rothman JE (1998) Visualizing secretion and synaptic transmission with $\mathrm{pH}$-sensitive green fluorescent proteins. Nature 394:192-195. CrossRef Medline

Nakayama FS (1971) Magnesium complex and ion-pair in Mgco3-Co2 solution system. J Chem Eng Data 16:178-181. CrossRef

Park SJ, Itoh T, Takenawa T (2001) Phosphatidylinositol 4-phosphate 5-kinase type I is regulated through phosphorylation response by extracellular stimuli. J Biol Chem 276:4781-4787. CrossRef Medline

Pavlov I, Kaila K, Kullmann DM, Miles R (2013) Cortical inhibition, pH and cell excitability in epilepsy: what are optimal targets for antiepileptic interventions? J Physiol 591:765-774. CrossRef Medline

Reardon EJ, Langmuir D (1974) Thermodynamic properties of ion-pairs $\mathrm{Mgco} 30$ and Caco30 from 10 to $50^{\circ} \mathrm{C}$. Am J Sci 274:599-612. CrossRef

Ruusuvuori E, Huebner AK, Kirilkin I, Yukin AY, Blaesse P, Helmy M, Kang HJ, El Muayed M, Hennings JC, Voipio J, Šestan N, Hubner CA, Kaila K (2013) Neuronal carbonic anhydrase VII provides GABAergic excitatory drive to exacerbate febrile seizures. EMBO J 32:2275-2286. CrossRef Medline

Schaer H (1974) Decrease in ionized calcium by bicarbonate in physiological solutions. Pflugers Arch 347:249-254. CrossRef Medline

Schwaller B (2010) Cytosolic Ca2 + buffers. Cold Spring Harb Perspect Biol 2:a004051. CrossRef Medline

Schwiening CJ, Boron WF (1994) Regulation of intracellular pH in pyramidal neurones from the rat hippocampus by $\mathrm{Na}(+)$-dependent $\mathrm{Cl}^{-}-$ HCO3 ${ }^{-}$exchange. J Physiol 475:59-67. Medline

Scott K (2011) Out of thin air: sensory detection of oxygen and carbon dioxide. Neuron 69:194-202. CrossRef Medline

Staley KJ, Soldo BL, Proctor WR (1995) Ionic mechanisms of neuronal excitation by inhibitory GABAA receptors. Science 269:977-981. CrossRef Medline

Storm JF (1987a) Intracellular injection of a Ca-2+ chelator inhibits spike repolarization in hippocampal-neurons. Brain Res 435:387-392. CrossRef Medline

Storm JF (1987b) Action-potential repolarization and a fast afterhyperpolarization in rat hippocampal pyramidal cells. J Physiol 385:733759. Medline

Storm JF (1989) An after-hyperpolarization of medium duration in rat hippocampal pyramidal cells. J Physiol 409:171-190. Medline

Suh BC, Hille B (2008) PIP2 is a necessary cofactor for ion channel function: how and why? Annu Rev Biophys 37:175-195. CrossRef Medline

Szabadics J, Varga C, Molnár G, Oláh S, Barzó P, Tamás G (2006) Excitatory effect of GABAergic axo-axonic cells in cortical microcircuits. Science 311:233-235. CrossRef Medline

Telezhkin V, Brown DA, Gibb AJ (2012) Distinct subunit contributions to the activation of M-type potassium channels by PI(4,5)P2. J Gen Physiol 140:41-53. CrossRef Medline

Trapp S, Lückermann M, Kaila K, Ballanyi K (1996) Acidosis of hippocampal neurones mediated by a plasmalemmal $\mathrm{Ca} 2+/ \mathrm{H}+$ pump. Neuroreport 7:2000-2004. CrossRef Medline

Tresguerres M, Buck J, Levin LR (2010) Physiological carbon dioxide, bicarbonate, and pH sensing. Pflugers Arch 460:953-964. CrossRef Medline

Tzingounis AV, Nicoll RA (2008) Contribution of KCNQ2 and KCNQ3 to the medium and slow afterhyperpolarization currents. Proc Natl Acad Sci U S A 105:19974-19979. CrossRef Medline

Woodruff A, Xu Q, Anderson SA, Yuste R (2009) Depolarizing effect of neocortical chandelier neurons. Front Neural Circuits 3:15. CrossRef Medline

Wu WW, Chan CS, Surmeier DJ, Disterhoft JF (2008) Coupling of L-type $\mathrm{Ca} 2+$ channels to KV7/KCNQ channels creates a novel, activitydependent, homeostatic intrinsic plasticity. J Neurophysiol 100:18971908. CrossRef Medline

Zaydman MA, Silva JR, Delaloye K, Li Y, Liang H, Larsson HP, Shi J, Cui J (2013) Kv7.1 ion channels require a lipid to couple voltage sensing to pore opening. Proc Natl Acad Sci U S A 110:13180-13185. CrossRef Medline

Zhang H, Craciun LC, Mirshahi T, Rohács T, Lopes CM, Jin T, Logothetis DE (2003) PIP(2) activates KCNQ channels, and its hydrolysis underlies receptor-mediated inhibition of $\mathrm{M}$ currents. Neuron 37:963-975. CrossRef Medline 